\title{
Physiological influences can outweigh environmental signals in otolith microchemistry research
}

\author{
Anna M. Sturrock ${ }^{1,4, *}$, Clive N. Trueman ${ }^{1}$, J. Andy Milton ${ }^{1}$, Colin P. Waring ${ }^{2}$, \\ Matthew J. Cooper ${ }^{1}$, Ewan Hunter ${ }^{3}$ \\ ${ }^{1}$ Ocean and Earth Science, National Oceanography Centre Southampton, University of Southampton Waterfront Campus, \\ European Way, Southampton, Hampshire SO14 3ZH, UK \\ ${ }^{2}$ University of Portsmouth, Institute of Marine Sciences, Ferry Road, Eastney, Hampshire PO4 9LY, UK \\ ${ }^{3}$ Centre for Environment, Fisheries and Aquaculture Science, Lowestoft Laboratory, Pakefield Road, Lowestoft, \\ Suffolk NR33 0HT, UK
}

${ }^{4}$ Present address: Institute of Marine Sciences, A317 Earth \& Marine Sciences Building, University of California, Santa Cruz, 1156 High Street, Santa Cruz, California 95064, USA

\begin{abstract}
Most studies that infer geographic distributions of fish using otolith microchemistry assume that environmental factors (e.g. temperature, salinity) outweigh intrinsic effects (e.g. size, condition); however, this assumption has not been rigorously tested, particularly in marine fish. Here, we report the results of a long-term experimental study of European plaice Pleuronectes platessa L. and explore relationships between blood plasma and ambient water chemistry over a 12 mo reproductive cycle. Overall, blood plasma was found to be highly regulated, with few elements exhibiting strong, if any, correlation with ambient concentrations. This sets a first order limit on the sensitivity of otolith chemistry to fluctuations in ambient seawater chemistry. The observed temporal, ontogenetic and sex-specific variations in blood plasma elemental concentrations indicated significant physiological influences on elemental uptake and processing mechanisms. Physiological variables exerted relatively strong influences on the uptake and regulation of the softer, more thiophilic elements (Mn, Cu, Zn, Se and Pb), as well as $\mathrm{Sr}$ and Ca. By contrast, seasonal and sex-related variations were relatively minor among the hard acid metal ions $\left(\mathrm{Li}^{+}, \mathrm{Mg}^{2+}\right.$, $\mathrm{K}^{+}, \mathrm{Rb}^{+}, \mathrm{Ba}^{2+}$ ). Overall, plasma elemental concentrations covaried most strongly and consistently with plasma protein concentrations. For this exclusively marine species, seasonal changes in physiology governed intra-annual variations in blood chemistry and, by implication, also regulate ion availability to the otolith. Based on these observations, we recommend that sex and age should be controlled for in future experimental designs using otolith microchemistry to infer stock structure or migration patterns.
\end{abstract}

KEY WORDS: Trace metals $\cdot$ Blood plasma $\cdot$ Otolith microchemistry $\cdot$ Plaice $\cdot$ Reproductive cycles

\section{INTRODUCTION}

The chemical composition of biomineralised structures such as fish otoliths reflects, at least in part, the physicochemical conditions of the surrounding environment, and comparisons of tissue chemistry are com- monly used to infer population structure and individual movements (Campana 1999). It is widely accepted that the mechanisms controlling uptake and incorporation of elements into the otolith are mediated by both exogenous (e.g. salinity) and endogenous (e.g. growth) factors (Walther et al. 2010). For most otolith 
microchemistry applications, it is assumed that environmental 'signals' outweigh physiological 'noise'; however, their relative importance is poorly understood and can vary among species, habitats, populations and life stages (Walther et al. 2010, Clarke et al. 2011).

To pass from the environment to the otolith, elements (or ions) must be transferred across several key interfaces. The mechanisms controlling the composition of otoliths can be viewed as a series of barriers or filters, each of which potentially alters the absolute or relative concentration of elements available for transfer (e.g. Campana 1999). Movement of ions between the environment and blood represents the first and potentially most complex of these barriers. This initial step is likely to be regulated for all elements to some degree, as the persistence of internal homeostasis is vital to health and survival, and the circulatory system is integral to maintaining ionic balance (Evans 1993). Fish blood is in constant flux, with elements assimilated via the gills, gut and tissue turnover and removed by excretion and storage in different tissues. Approximately half of the blood fluid is comprised of plasma, which contains dissolved ions, proteins, metabolites, hormones, platelets and waste products (Williams 1971). Blood proteins are critical in the transport of many trace elements, and can vary in concentration and composition (and, thus, relative metal-binding capacity) in response to the physiological and nutritional status of the individual (e.g. Hille 1982). Such variations in blood protein composition provide a clear mechanism for the physiological fractionation of elements between the environment, blood and otolith (Kalish 1991).

Seasonal cycles in elemental concentrations have been observed in the blood plasma, endolymph and otoliths of mature adults of the bearded rock cod Pseudophysis barbatus, an exclusively marine species (Kalish 1991). Otolith Sr/Ca ratios were largely explained by physiological factors and were hypothesised to vary as a function of protein composition, questioning the importance of environmental controls on this frequently applied otolith marker (Kalish 1991). More recently, laboratory studies have provided insight into ion movement pathways between plasma, endolymph and otoliths (e.g. Tohse \& $\mathrm{Mu}-$ giya 2001, Payan et al. 2002, 2004a) and relationships between manipulated conditions and otolith concentrations (e.g. Bath et al. 2000, Hicks et al. 2010, Miller 2011). However, such experiments tended to focus on a limited suite of elements (primarily $\mathrm{Sr}$ and $\mathrm{Ba}$ ), using larval or juvenile fish grown in simplified and exaggerated conditions that do not reflect the environmental experiences of fully marine species. Des- pite known ontogenetic shifts in elemental processing (e.g. De Pontual et al. 2003), few studies have examined elemental uptake mechanisms in adult fish (e.g. Melancon et al. 2009), in part because of the considerable challenges associated with their longterm maintenance. Investigations into seasonal and ontogenetic changes in fish blood elemental chemistry are even fewer (Sturrock et al. 2013). Given continued growth in the field of otolith microchemistry (Sturrock et al. 2012) and increasing subtlety of the questions being asked (Elsdon et al. 2008), there is a critical need for an improved understanding of element uptake and processing mechanisms and, thus, the fundamental assumptions underpinning the use of otolith microchemistry in fish ecology.

In the present study, we quantified monthly concentrations of 12 elements in the blood plasma of male and female European plaice Pleuronectes platessa L. maintained in near-natural conditions for $1 \mathrm{yr}$. The elements were broadly organised into 3 categories: Group I and Group II 'hard acid metal ions' ( $\mathrm{Li}, \mathrm{K}, \mathrm{Rb}$; $\mathrm{Mg}, \mathrm{Ca}, \mathrm{Sr}, \mathrm{Ba}$ ) and more thiophilic 'soft acid metal ions' (Mn, $\mathrm{Cu}, \mathrm{Zn}, \mathrm{Se}, \mathrm{Pb}$ ) (after Sturrock et al. 2012). Our objective was to determine the environmental and/or physiological factors driving variations in blood microchemistry in this exclusively marine fish.

\section{MATERIALS AND METHODS}

\section{Animal collection and experimental design}

Wild plaice were collected by beam trawl from Liverpool Bay in the Irish Sea (IS) in February 2009 (n = 56) and from the English Channel (EC) near Eastbourne, UK, in August $2009(\mathrm{n}=22)$. The fish were transported to the Centre for Environment, Fisheries and Aquaculture Science (CEFAS) Lowestoft aquarium and maintained in a single $9 \mathrm{~m}^{3}$ outdoor tank supplied with continuously flowing, directly sourced coastal seawater. The tank roof was open during daylight hours (avoiding exposure to direct sunlight) to establish natural photoperiodism. The fish were not handled for at least 2 mo following transfer to this regime to ensure that common blood parameters had returned to basal levels (Bourne 1986). The fish were fed twice weekly using a generous diet of live lugworms Arenicola marina sourced from a single nearby beach, equivalent to $2.5 \%$ total weight per day (Horwood et al. 1989). Uneaten food was removed within $24 \mathrm{~h}$. Blood sampling was carried out between 08:00 $\mathrm{h}$ and 10:00 $\mathrm{h}$ on days prior to feeding to avoid diurnal or food-related artefacts. 
During the year-long 'common garden' experiment, a suite of physiological and environmental variables were monitored on a daily to monthly basis, as described below. All experiments were performed in compliance with Home Office guidelines (Project License no. 80/2260).

\section{Physiological variables}

Blood samples and physiological data were collected on a monthly basis. On each sampling day, total length (TL), total weight (TW), Fulton's condition factor $\left(\mathrm{TW}^{\mathrm{T}} \mathrm{TL}^{3} \times 100\right)$ and average daily growth rate $(\Delta \mathrm{TL} / \Delta \mathrm{d})$ were recorded, and female plaice were photographed for estimation of the gonadosomatic index (GSI).

\section{Gonadosomatic index}

GSI was estimated using the non-destructive methods of Kennedy et al. (2008). Photographs of the females were taken on a lightbox, and the area of the ovary shadow posterior to the body cavity was measured using ImageJ (Abramoff et al. 2004). The relationship between ovary area $\left(\mathrm{O}_{\mathrm{a}}\right.$, average of 3 blind measurements) and ovary mass $\left(\mathrm{O}_{\mathrm{m}}\right)$ was calibrated using the ovaries from females that died during the study or that were sacrificed on completion of the experiment. This relationship was used to generate monthly estimates of $\mathrm{O}_{\mathrm{m}}$ and GSI $\left(\mathrm{O}_{\mathrm{m}} / \mathrm{TW} \times 100\right)$. Given that no females died during the spawning season, measurements from 6 gravid plaice from Kennedy et al. (2008) were used to constrain the upper bounds of the calibration curve.

\section{Blood sampling and analysis}

Blood samples (usually $<0.3 \mathrm{ml}$ ) were collected by caudal venepuncture for elemental and protein analyses. On the first sampling day (2 June 2009 for IS fish, 27 October 2009 for EC fish), individuals were injected into the body cavity with oxytetracycline (Oxytetrin 20 LA, Schering Plough; dose rate $50 \mathrm{mg}$ $\mathrm{kg}^{-1}$ TW) to leave a visible 'start check' on the otolith for use in a companion study (Sturrock 2012). The oxytetracycline was pre-diluted using a plaicespecific Ringers solution $\left(8.22 \mathrm{mg} \mathrm{ml}^{-1} \mathrm{NaCl}\right.$ in Milli$\mathrm{Q}$ water, after Cobb et al. 1973) to reduce osmotic shock, and was administered after the blood had been collected. Passive integrated transponder tags (www. wyremicrodesign.co.uk) were inserted intramuscularly to provide each fish with a unique identification code. At the start of the spawning season (18 January 2010), approximately half the fish were treated with gonadotropin-releasing hormone (GnRH) to encourage spawning, and an additional sampling date was added in February. On termination of the experiment (28 May 2010), animals were sacrificed and their ages determined by counting translucent growth bands on otolith transverse sections.

Full details of blood treatment and analysis are provided in Sturrock et al. (2013). In brief, samples were centrifuged within $3 \mathrm{~h}$ of collection and the plasma extracted for protein and elemental analyses and were then stored at $-20^{\circ} \mathrm{C}$. Because of resource limitations, not all blood samples could be analysed, so following termination of the experiment, samples belonging to individuals with higher otolith growth rates were prioritized ( $\mathrm{n}=19$; 6 IS males, 7 IS females, 6 EC females), along with 6 randomly selected fish (4 IS males, 1 IS female, $1 \mathrm{EC}$ female). The results presented hereafter relate only to this subset of fish $(\mathrm{n}=25)$.

Total (bound and unbound) concentrations of $\mathrm{Li}$, $\mathrm{Mg}, \mathrm{K}, \mathrm{Ca}, \mathrm{Mn}, \mathrm{Cu}, \mathrm{Zn}, \mathrm{Se}, \mathrm{Rb}, \mathrm{Sr}, \mathrm{Ba}$ and $\mathrm{Pb}$ in blood plasma were quantified using high-resolution inductively coupled plasma-mass spectrometry (HR-ICPMS; ELEMENT XR, Thermo Fisher Scientific) and external calibration using synthetic standards prepared from single element standards (Inorganic Ventures and ROMIL). Samples and standards were internally spiked to correct for any matrix differences. Accuracy and precision were assessed using Seronorm reference material and procedural standards (detailed in Sturrock et al. 2013).

Total plasma protein was determined using the Biuret test (Harding et al. 1978). Standards were made in replicate using bovine serum albumin (Sigma-Aldrich) and concentrations calculated by volume, using direct calibration and Standard Curve software. When blood sampling efforts were less successful and low volumes of plasma obtained, resampling was not attempted, and elemental analyses were prioritised over protein analyses. Missing protein values $(n=12$ of 282 ) were replaced with the mean of the previous and subsequent measurements for the same individual.

\section{Environmental sampling}

The CEFAS Lowestoft aquarium sources its seawater directly from a proximal offshore filter. Consequently, water temperature, salinity and elemental 
concentrations varied with ambient conditions, except during summer months, when water temperatures were capped at $\sim 14^{\circ} \mathrm{C}$ for welfare reasons. Tank temperature was monitored daily and salinity measured weekly at the CEFAS nutrient laboratory.

Water sampling for elemental analysis was carried out on a near-weekly basis using acid-cleaned consumables (after Kremling 1999) and acid-cleaned $0.2 \mu \mathrm{m}$ nylon Millex $^{\odot}$ filters. Samples were acidified using sub-boiled trace metal grade $\mathrm{HNO}_{3}$ (Fisher Scientific) and stored at $-20^{\circ} \mathrm{C}$. Milli-Q water (>18.2 M $\Omega$ ) blanks were prepared in an identical manner. Aliquots were diluted 1000 -fold and analysed for ${ }^{24} \mathrm{Mg},{ }^{39} \mathrm{~K},{ }^{44} \mathrm{Ca}$ and ${ }^{88} \mathrm{Sr}$ by quadrupole ICPMS (XSERIES 2, Thermo Fisher Scientific) in peak jumping mode, operated with an RF power of $1400 \mathrm{~W}$ using a Peltier cooled cyclonic/impact bead-type spray chamber and standard Ni Xt sample and skimmer cones. Typical auxiliary and cooling gas flows were 0.8 and $131 \mathrm{~min}^{-1}$, respectively. Additional aliquots were diluted 15 -fold and analysed in low $\left({ }^{7} \mathrm{Li}\right.$, $\left.{ }^{85} \mathrm{Rb},{ }^{86} \mathrm{Sr},{ }^{137} \mathrm{Ba},{ }^{208} \mathrm{~Pb}\right)$, medium $\left({ }^{55} \mathrm{Mn},{ }^{65} \mathrm{Cu},{ }^{66} \mathrm{Zn}\right)$ and high $\left({ }^{77} \mathrm{Se},{ }^{78} \mathrm{Se}\right)$ resolution mode by HR-ICP-MS (ELEMENT XR). ${ }^{118} \mathrm{Sn}$ was monitored in case of interferences on ${ }^{115} \mathrm{In}$. Multi-element standard solutions were prepared using 3\% sub-boiled $\mathrm{HNO}_{3}$ and single element standards (Inorganic Ventures and ROMIL). Samples and standards were spiked with internal standards (Be at $10 \mathrm{ng} \mathrm{g}^{-1}$, In and Re at $5 \mathrm{ng}$ $\mathrm{g}^{-1}$ ) to correct for instrument drift and signal suppres- sion, and NASS-5 (nearshore seawater reference material for trace metals, National Research Council Canada) was used as a 'base' in the calibration series to improve matrix matching between standards and samples. NASS-5 is characterised by low heavy metal content but was diluted $1.2 \times$ beforehand to ensure points above and below the unknowns in each calibration curve. Concentrations were calculated by weight. To estimate external precision and accuracy, CASS-4 (nearshore seawater reference material, National Research Council Canada) and a randomly selected seawater sample ('procedural standard') were analysed throughout the run.

Raw counts were drift-corrected and blank-subtracted offline. Concentrations in the NASS-5 'base' were determined by standard addition and accounted for within the external calibration curves (all $\mathrm{r}^{2}>$ 0.999). Estimates of precision and limits of detection (LOD) are provided in Table 1. In the seawater samples, $55 \%$ of $\mathrm{Zn}$ and $2 \%$ of Mn measurements were $<$ LOD, but all other elements were $>$ LOD. In the CASS-4 samples, all elements were $>$ LOD except for $\mathrm{Zn}$; however, the mean measured Zn concentration (including sub-LOD measurements) was almost within the certified range (Table 1). As the method for setting LOD is somewhat arbitrary and can lead to the loss of potentially valuable information, some studies include sub-LOD values in their datasets (e.g. Ben-Tzvi et al. 2007). Here, it was impossible to obtain matrix-matched blanks, leading to further

Table 1. Limits of detection (LOD, $3 \mathrm{SD}$ of procedural blanks, corrected to relevant dilution factor) and average internal and external precision for seawater analyses carried out on the XSERIES 2 inductively coupled plasma-mass spectrometer (ICPMS) and ELEMENT XR high-resolution ICP-MS. Zn concentrations were <LOD in the procedural standard and CASS-4 reference material, but were still included in the dataset. Accuracy was assessed using certified acceptable ranges for CASS-4 where available; all except $\mathrm{Zn}$ were within range. RSD = relative standard deviation

\begin{tabular}{|c|c|c|c|c|c|c|c|}
\hline & & \multirow[t]{2}{*}{$\begin{array}{c}\text { LOD } \\
\left(\mathrm{ng} \mathrm{g}^{-1}\right)\end{array}$} & \multirow{2}{*}{$\begin{array}{l}\text { Internal } \\
(\mathrm{n}=56)\end{array}$} & \multicolumn{2}{|c|}{$\begin{array}{l}\text { Precision (\%RSD) } \\
\quad \text { External }-\end{array}$} & \multicolumn{2}{|c|}{$\begin{array}{c}\text { - CASS-4 concentration - } \\
\left(\mathrm{ng} \mathrm{g}^{-1}\right)\end{array}$} \\
\hline & & & & $\begin{array}{l}\text { Procedural } \\
\text { standard (n) }\end{array}$ & $\begin{array}{l}\text { CASS-4 } \\
(\mathrm{n}=4)\end{array}$ & $\begin{array}{l}\text { Measured } \\
(\mathrm{n}=4)\end{array}$ & $\begin{array}{l}\text { Certified } \\
\text { range }\end{array}$ \\
\hline \multicolumn{8}{|l|}{ XSERIES 2} \\
\hline \multirow[t]{4}{*}{$1000 \times$ dilution } & $\mathrm{Mg}$ & 0.071 & 0.98 & $1.81(4)$ & 0.57 & $1.115 \times 10^{6}$ & - \\
\hline & $\mathrm{K}$ & 1.5 & 1.06 & $1.81(4)$ & 0.78 & $3.34 \times 10^{5}$ & - \\
\hline & $\mathrm{Ca}$ & 1.8 & 1.56 & $0.77(4)$ & 1.18 & $3.44 \times 10^{5}$ & - \\
\hline & $\mathrm{Sr}$ & 0.0013 & 0.62 & $0.76(4)$ & 0.64 & $6.31 \times 10^{3}$ & - \\
\hline \multicolumn{8}{|l|}{ ELEMENT XR } \\
\hline \multirow[t]{8}{*}{$15 \times$ dilution } & $\mathrm{Li}$ & 0.27 & 1.84 & $0.46(3)$ & 1.61 & 152.78 & - \\
\hline & $\mathrm{Mn}$ & 0.13 & 3.02 & $2.87(3)$ & 0.83 & 2.93 & $2.59-2.97$ \\
\hline & $\mathrm{Cu}$ & 0.04 & 1.98 & $2.82(3)$ & 6.46 & 0.631 & $0.537-0.647$ \\
\hline & $\mathrm{Zn}$ & 4.00 & 4.51 & $15.4(3)$ & 52.5 & 0.308 & $0.324-0.438$ \\
\hline & $\mathrm{Se}$ & 0.012 & 1.76 & 3.17 (3) & 7.95 & 0.063 & - \\
\hline & $\mathrm{Rb}$ & 0.0095 & 1.31 & $1.05(3)$ & 0.64 & 110.92 & - \\
\hline & $\mathrm{Ba}$ & 0.029 & 1.00 & $0.68(3)$ & 0.25 & 6.84 & - \\
\hline & $\mathrm{Pb}$ & 0.015 & 2.69 & $1.16(3)$ & 30.04 & 0.0097 & $0.0062-0.0134$ \\
\hline
\end{tabular}


ambiguity in the setting of the LOD. Also, as $\mathrm{Zn}$ is a highly mobile element (Versieck \& Cornelis 1989), exclusion of sub-LOD values was deemed likely to skew the dataset towards potentially contaminated samples. For these reasons, all measurements were retained. Congruence in temporal trends among the 'soft' metals ( $\mathrm{Zn}, \mathrm{Cu}$ and $\mathrm{Pb}$ in particular) instilled further confidence in the Zn measurements; however, the results should be taken with caution. Accuracy was otherwise deemed satisfactory, with $\mathrm{Cu}, \mathrm{Mn}$ and $\mathrm{Pb}$ measurements all within certified ranges (Table 1). Outliers (>median + 3 SD) were excluded.

\section{Data analysis}

All data analyses were carried out using $\mathrm{R}$ software. Note that throughout this article, ' $\mathrm{El}_{\mathrm{X}}$ ' represents element concentrations in medium ' $\mathrm{X}$ ', and 'El/Cax' represents the ratio of element to $\mathrm{Ca}$ concentrations in medium ' $\mathrm{X}$ ', where ' $\mathrm{X}$ ' is either water $(\mathrm{w})$ or blood plasma ${ }_{\mathrm{B}}$ ).

\section{Smoothing}

While physiological sampling was carried out at least once per month, there was variability in sampling dates within each month. As such, local polynomial regression fitting (LOESS) was used to smooth data and predict temperature, salinity, $\mathrm{El}_{\mathrm{W}}$ and $E l / C a_{W}$ values for specific sampling dates. LOESS fits a polynomial model using a weighted least squares linear regression and a variable 'span' or window size (Cleveland et al. 1992). For temperature and salinity, a narrower window was used (span $=0.25)$. $\mathrm{El}_{\mathrm{W}}$ and $\mathrm{El} / \mathrm{Ca}_{\mathrm{W}}$ were generally noisier, presumably because of lower sampling frequency and greater processing and instrument error. To avoid over-fitting these data, a span of 0.5 (equivalent to an approximately $3 \mathrm{wk}$ moving average) was used, and a span of 0.6 was used for elements close to the LOD (Mn, Zn and Se).

\section{Modelling}

Linear mixed-effects (LME) models (lme4 package) were used to examine which physiological and/or environmental variables best explained variations in blood elemental concentrations. LME models allow for non-independence and autocorrelation of the response variable by inclusion of a random effect (in this case, the identity of the individual fish). We allowed intercepts to vary by individual (Crawley 2007, Zuur et al. 2009) and used a systematic model selection and assessment procedure. First, a 'global model' predicting $\mathrm{El}_{\mathrm{B}}$ was built including all fixed effects (sex, GnRH treatment, origin, temperature, salinity, $\mathrm{El}_{\mathrm{W}}, \mathrm{El} / \mathrm{Ca}_{\mathrm{W}}$, day, protein concentration, condition, growth rate, TL, age) and their first order interactions. For each element, models were built using data for all fish and for females only, including GSI. Where necessary, data were $\log _{10}$, natural log or square root transformed to meet assumptions of homogeneity and normally distributed residuals. Note that TW was excluded from the model selection criteria, as it was tightly correlated with TL $(\mathrm{r}=0.9)$, and TL and condition were considered more appropriate measures of fish size and 'fatness', respectively. First, the number of interactions was reduced using analysis of deviance (ANOVA, car package) and maximum likelihood methods. While p-values are generally incompatible with mixed-effects models because of the lack of an underlying F-distribution, they can still provide guidance on the relative importance of individual terms. As such, interactions displaying p-values $<0.01$ were retained, along with any deemed likely to have particular biological relevance. All single order terms were retained. Finally, the reduced model was standardized (arm package) to centre and scale the predictor and response variables, then analysed using restricted maximum likelihood estimation. Dredge (MuMIn package) was used to find the most parsimonious model(s) by ranking all possible models by the Akaike information criterion (AIC). AIC, also known as a 'penalised log-likelihood', measures model fit while penalising for the number of terms (Crawley 2007). A 'best model' was selected if it had $\triangle \mathrm{AIC}>2$ compared with all other candidates. If multiple models exhibited similarly low AIC values, then the model with the best performance (based on the criteria below) was selected, and any subjectivity was highlighted for further discussion.

Models were judged to be 'performing well' if they exhibited low multicollinearity (variance inflation factor < 5, 'kappa' < 30) and their residual structure was normally distributed, homogeneous and exhibited low autocorrelation. Model fit and the proportion of variance explained by fixed and random effects were estimated using Nagelkerke pseudo- ${ }^{2}$ values (Nagelkerke 1991), and p-values were assigned to individual terms using analysis of deviance. 


\section{Correlations and distribution coefficients}

Pearson product-moment correlation coefficients (r) were used to indicate coarse relationships among variables, primarily focusing on $\mathrm{El}_{\mathrm{W}} \mathrm{vs} \mathrm{El}_{\mathrm{B}}$ pairwise correlations. To examine relative enrichment of the blood relative to ambient concentrations, distribution coefficients from seawater to blood were calculated as $\mathrm{D}_{\mathrm{El}(\mathrm{B} / \mathrm{W})}=\mathrm{El}_{\mathrm{B}} / \mathrm{El}_{\mathrm{W}}$.

\section{RESULTS}

\section{Physiological conditions}

$\mathrm{O}_{\mathrm{m}}$ (in $\mathrm{g}$ ) was significantly related to $\mathrm{O}_{\mathrm{a}}$ (in $\mathrm{cm}^{2}$ ) by a polynomial relationship $\left(\mathrm{r}^{2}=0.98, \mathrm{n}=41, \mathrm{p}<\right.$ 0.0001):

$$
\begin{aligned}
& \mathrm{O}_{\mathrm{m}}=\left[0.13( \pm 0.008 \mathrm{SE}) \times \mathrm{O}_{\mathrm{a}}\right]^{2}- \\
& {\left[0.58( \pm 0.21 \mathrm{SE}) \times \mathrm{O}_{\mathrm{a}}\right]+2.03( \pm 1.05 \mathrm{SE})}
\end{aligned}
$$

Estimated GSI values ranged from 0.33 to $30.4 \%$, which is within realistic ranges for flatfish (e.g. Maddock \& Burton 1998). The IS males and females were generally mature and similar in age, and despite being larger, the EC females were younger and predominantly immature (Table 2, Fig. 1d), with significantly lower GSI than the IS females at the height of the spawning season (5.1 vs. $15.4 \%$ in March 2010, $\left.F_{1,13}=6.27, \mathrm{p}=0.026\right)$. Only 1 EC female spawned, while a GnRH-treated female had ovaries full of unhydrated eggs at the end of the experiment in May, which likely would have been resorbed through atresia. Of the IS females, only 1 individual ( 4 yr old) exhibited no ovary development and was deemed immature.

During the 12 mo experiment, mean TL increased by $2.5 \mathrm{~cm} \pm 0.62 \mathrm{SE}$ in the IS females [t(7) $=4.01 \mathrm{p}=$ $0.005]$ and by $2.7 \mathrm{~cm} \pm 0.47 \mathrm{SE}$ in the males [t$(9)=$ $5.80 \mathrm{p}<0.001]$, and mean TW increased by $102.1 \mathrm{~g} \pm$ 21.5 SE $[t(7)=4.74 \mathrm{p}=0.002]$ and $72.8 \mathrm{~g} \pm 11.4 \mathrm{SE}$ $[t(9)=6.37 \mathrm{p}<0.001]$, respectively. The EC females were introduced to the experiment 4 mo later, and while their mean TL increased by $1.1 \mathrm{~cm}(3.4 \%)$ and TW increased by $17.7 \mathrm{~g} \mathrm{(5.0 \% ),} \mathrm{these} \mathrm{changes} \mathrm{were}$ not significant $(\mathrm{p}>0.05)$. Growth rates were highly variable among individuals. The EC females grew more slowly than the IS fish when first introduced, but there was no difference among groups at the end of the experiment $(p>0.05)$. Growth rates of the IS fish peaked in October and November but slowed during the winter spawning season, particularly in the females (Fig. 1b).

Condition and plasma protein concentrations followed similar trends over time $(r=0.6)$, increasing until the start of the spawning season (December) then falling until the end of the experiment (Fig. 1a,c). Both measures tended to be lower in the EC females, particularly during the spawning season (Fig. 1a,c). On termination of the experiment, condition did not differ between groups (Table $2, \mathrm{p}>0.05$ ), but plasma protein concentrations were significantly lower in the EC females than in the IS females ( $p<$ 0.05, Tukey's test). Plasma protein concentrations were positively correlated with growth rate $(\mathrm{r}=0.4)$ and GSI $(r=0.4)$, while water temperature was negatively correlated with condition $(\mathrm{r}=-0.5)$, TW $(\mathrm{r}=$ $-0.4)$ and GSI $(\mathrm{r}=-0.3)$.

\section{Environmental conditions}

Water temperature varied seasonally $\left(3.8\right.$ to $14.9^{\circ} \mathrm{C}$, Fig. 2) and was typical of the range experienced by wild North Sea plaice (Hunter et al. 2004). Salinity ranged from 30.1 to 33.3 and generally followed the same trend as temperature but lagged by 1 to 2 mo (Fig. 2).

Seawater elemental concentrations generally followed similar trends to salinity, reaching a minimum in early February (Fig. 3). Concentrations of the conservative elements ( $\mathrm{Li}, \mathrm{Rb}, \mathrm{K}, \mathrm{Mg})$ and quasiconservative elements ( $\mathrm{Ca}$, $\mathrm{Sr}_{\text {; }}$ Steele et al. 2009) varied with salinity, fluctuating in a sinusoidal manner

Table 2. Average $( \pm \mathrm{SD})$ total length $(\mathrm{TL})$, total weight $(\mathrm{TW})$, growth rate $(\mathrm{GR})$, Fulton's condition factor (Condition), gonadosomatic index (GSI) and age of selected subject animals at the end of the experiment (28 May 2010). EC = English Channel, IS = Irish Sea, na = not available

\begin{tabular}{|lcrcccccc|}
\hline Origin & Sex & \multicolumn{1}{c}{$\mathrm{n}$} & TL $(\mathrm{cm})$ & TW $(\mathrm{g})$ & Overall GR $\left(\mathrm{mm} \mathrm{d}^{-1}\right)$ & Condition & GSI (\%) & Age $(\mathrm{yr})$ \\
\hline IS & $\mathrm{M}$ & 10 & $27.22 \pm 2.38$ & $208.6 \pm 51.01$ & $0.075 \pm 0.041$ & $1.02 \pm 0.08$ & na \\
IS & $\mathrm{F}$ & 8 & $30.84 \pm 2.01$ & $293.3 \pm 67.84$ & $0.069 \pm 0.049$ & $0.98 \pm 0.05$ & $3.18 \pm 2.12$ & $5.4 \pm 2.5$ \\
EC & $\mathrm{F}$ & 7 & $33.54 \pm 1.75$ & $370.7 \pm 95.00$ & $0.052 \pm 0.064$ & $0.97 \pm 0.13$ & $2.76 \pm 4.06$ & $3.4 \pm 0.79$ \\
\hline
\end{tabular}



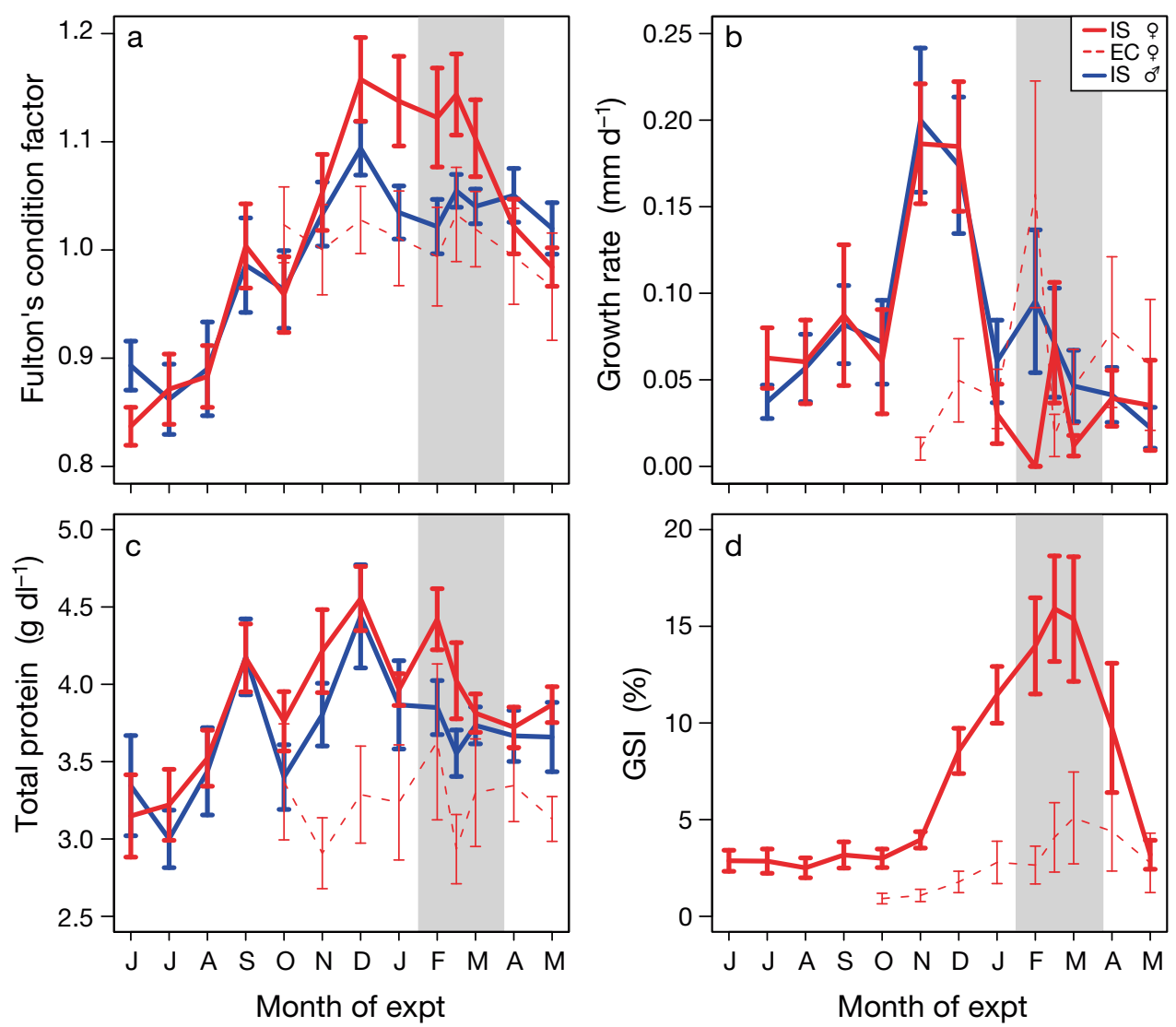

Fig. 1. Monthly mean $( \pm \mathrm{SE})$ (a) condition, (b) growth rate, (c) blood plasma protein concentrations and (d) female gonadosomatic index (GSI) of 25 plaice from the Irish Sea (IS) and English Channel (EC) serially sampled for 7 to 12 mo. Note that sampling was carried out twice in February, and mean daily growth rate was calculated as $\mathrm{TL}_{\text {month2 }}-$ $\mathrm{TL}_{\text {month1, }}$ so no values are assigned to the first sampling month in each group. Shading: peak spawning period. $\mathrm{TL}=$ total length, $\phi=$ female,$\sigma^{n}=$ male

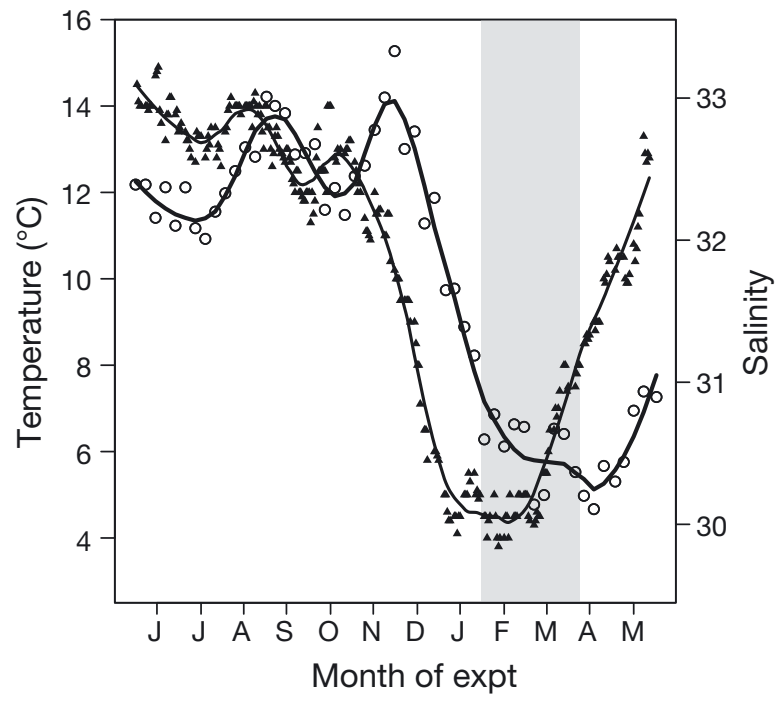

Fig. 2. Water temperature (₫) and salinity (O) during the experiment. Shading: peak spawning period

and returning to almost exactly the same concentration as they were $1 \mathrm{yr}$ earlier. There was little temporal variation in their El/Ca ratios. $\mathrm{Ba}_{\mathrm{W}}, \mathrm{Cu}_{\mathrm{W}}, \mathrm{Zn}_{\mathrm{W}}, \mathrm{Se}_{\mathrm{W}}$ and $\mathrm{Pb}_{\mathrm{W}}$ exhibited similar patterns over time but over proportionally greater amplitudes than the conservative elements, resulting in greater seasonal variability in their El/Ca ratios (Fig. 3). $\mathrm{Mn}_{\mathrm{W}}$, a scavenged element (Steele et al. 2009), was more difficult to interpret because of a lower signal-to-noise ratio but certainly differed from the other elements, remaining low until late December then increasing towards the end of the experiment.

\section{Variations in blood plasma elemental concentrations}

Blood plasma elemental concentrations $\left(\mathrm{El}_{\mathrm{B}}\right)$ varied over time and between groups (males, females, IS and EC fish) despite exposure to identical ambient concentrations, temperatures and diets (Fig. 4, Table 3). Note that seawater temperature and elemental concentrations $\left(\mathrm{El}_{\mathrm{W}}\right)$ often covaried and exhibited near-bimodal distributions; in these cases, it was impossible to fully separate their effects. Unless otherwise stated, the same terms were incorporated into the 'full' and 'female-only' models. 

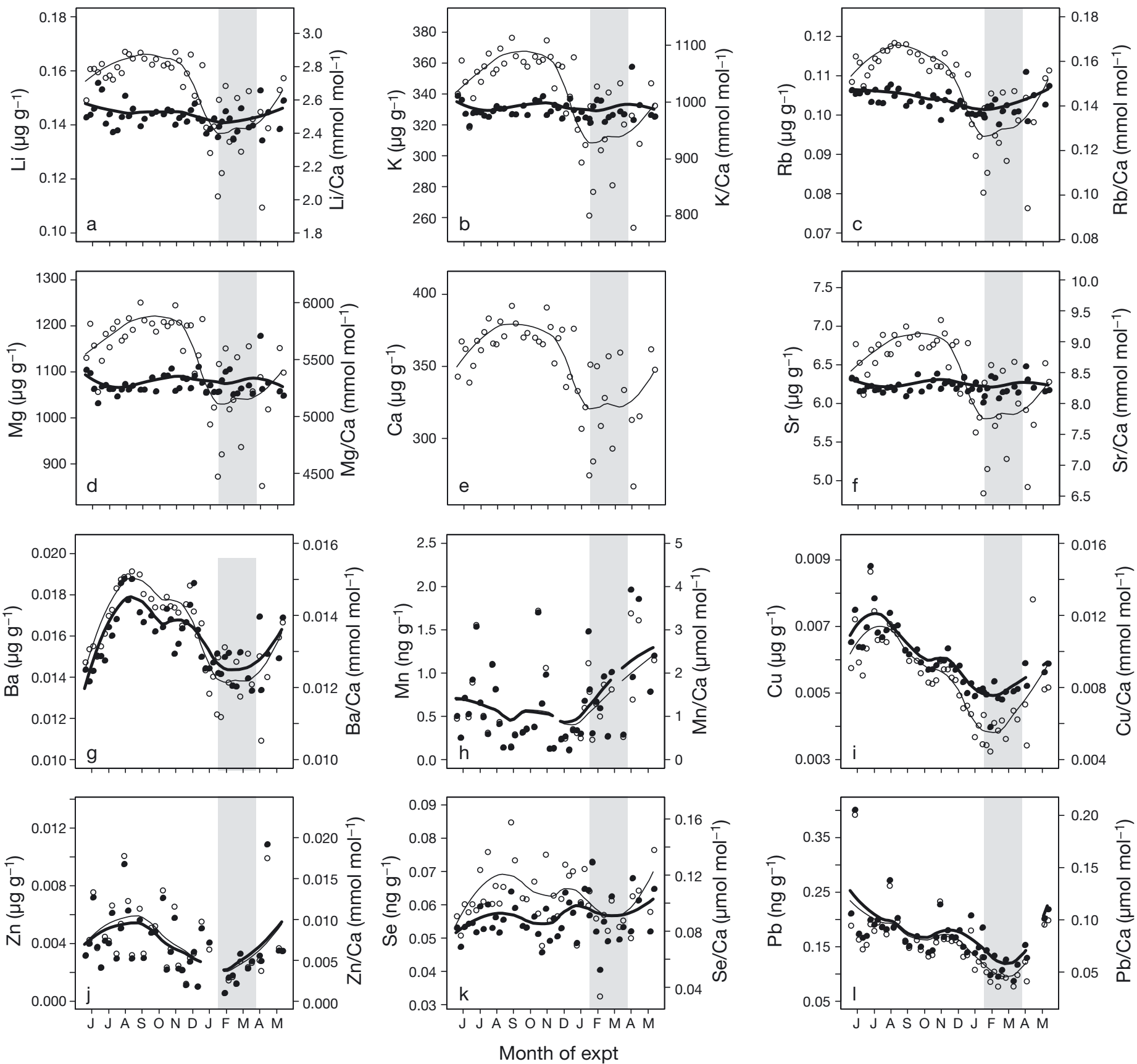

Fig. 3. Water element concentrations $\left(\mathrm{O}, \mu \mathrm{g} \mathrm{g}^{-1} \mathrm{or} \mathrm{ng}^{-1}\right)$ and El/Ca ratios $\left(\bullet, \mathrm{mmol} \mathrm{mol}^{-1}\right.$ or $\left.\mu \mathrm{mol}^{\mathrm{mol}}{ }^{-1}\right)$ during the experiment. The elements are ordered by mass and broad elemental groupings: Group I, Group II, then 'soft' (Sturrock et al. 2012) elements. Local polynomial regression fitting (LOESS) smoothers (displayed) were used to predict concentrations and El/Ca ratios for specific blood sampling days. Shading: peak spawning period

\section{Lithium}

$\mathrm{Li}_{\mathrm{B}}$ did not exhibit clear temporal trends, but concentrations were generally lower in early spring (Fig. 4a). Li $\mathrm{B}_{\mathrm{B}}$ values were higher in females than in males $(p<0.001)$ and positively correlated with tem- perature and salinity, although at the highest temperatures, $\mathrm{Li}_{\mathrm{B}}$ values were weakly negatively correlated with salinity. Both the full and female-only models exhibited a weak to moderate fit $\left(\mathrm{r}^{2}>0.25\right)$, with little variation explained by the random effect, implying similar responses among fish. 

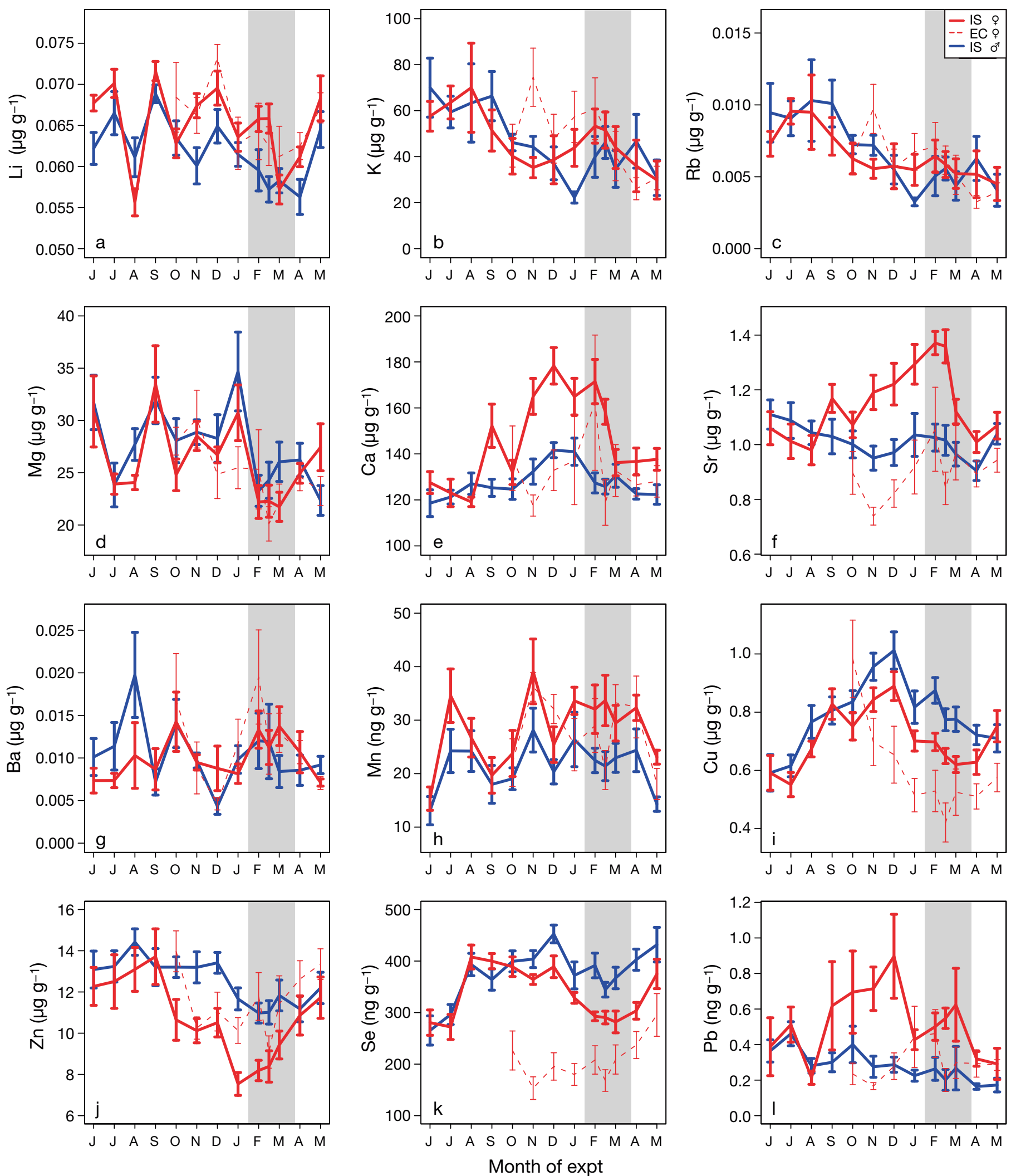

Fig. 4. Monthly mean $( \pm \mathrm{SE})$ blood plasma elemental concentrations (in $\mu_{\mathrm{g} \mathrm{g}} \mathrm{g}^{-1} \mathrm{or} \mathrm{ng} \mathrm{g}^{-1}$ ) in 25 plaice from the Irish Sea (IS) and English Channel (EC) serially sampled for 7 to 12 mo. Note that sampling was carried out twice in February. Shading: peak spawning period. $\stackrel{\varphi}{=}$ female, $o^{1}=$ male 
Table 3. Outputs of linear mixed-effects models predicting blood plasma elemental concentrations ( $\mathrm{El}_{\mathrm{B}}$ ) in 25 plaice sampled for 7 to 12 mo $(n=282)$. Analysis of deviance p-value and Nagelkerke pseudo- $r^{2}$ values (full model and fixed effects only) are displayed. Fixed effects include plasma protein concentrations (Protein), salinity (Sal) and temperature (Temp), among others. Gonadosomatic index (GSI) is displayed when included in the female-only model, alongside the model fit (shaded). EC $=$ English Channel, F = female, IS = Irish Sea, M = male, ns = not significant, +ve = positive, - ve = negative, $\uparrow=$ higher, $\downarrow=$ lower

\begin{tabular}{|c|c|c|c|c|c|c|}
\hline \multirow[t]{2}{*}{ Response } & \multirow[t]{2}{*}{ Fixed effect } & \multirow[t]{2}{*}{ Directionality of effect } & \multirow{2}{*}{$\underset{\text { statistic }}{\chi^{2}}$} & \multirow[t]{2}{*}{$\mathrm{p}$} & \multicolumn{2}{|c|}{ Model fit (pseudo-r²) } \\
\hline & & & & & Full model & Fixed effects \\
\hline \multirow[t]{4}{*}{$\mathrm{Li}_{\mathrm{B}}$} & Sex & $\mathrm{F}>\mathrm{M}$ & 11.59 & 0.0007 & \multirow[t]{4}{*}{0.26} & \multirow[t]{4}{*}{0.24} \\
\hline & Temp & & 0.821 & $\mathrm{~ns}$ & & \\
\hline & Salinity & +ve & 16.53 & $<0.0001$ & & \\
\hline & Temp $\times$ Sal & -ve/ns at $\downarrow$ Sal, +ve at $\uparrow$ Sal & 11.49 & 0.0007 & & \\
\hline \multirow[t]{3}{*}{$\mathrm{K}_{\mathrm{B}}$} & Day & -ve & 48.47 & $<0.0001$ & \multirow[t]{3}{*}{0.21} & \multirow[t]{3}{*}{0.18} \\
\hline & Protein & -ve & 13.78 & 0.0002 & & \\
\hline & Temp & +ve & 5.22 & 0.0223 & & \\
\hline \multirow{2}{*}{$\mathrm{Rb}_{\mathrm{B}}$} & Day & -ve & 62.98 & $<0.0001$ & \multirow{2}{*}{0.23} & \multirow[t]{2}{*}{0.21} \\
\hline & Protein & -ve & 8.58 & 0.0034 & & \\
\hline \multirow{3}{*}{$\mathrm{Mg}_{\mathrm{B}}$} & Protein & +ve & 15.29 & $<0.0001$ & \multirow[t]{3}{*}{0.17} & \multirow[t]{3}{*}{0.15} \\
\hline & Salinity & +ve & 33.95 & $<0.0001$ & & \\
\hline & Treatment & Treated $>$ untreated & 4.62 & 0.0316 & & \\
\hline \multirow[t]{4}{*}{$\mathrm{Ca}_{\mathrm{B}}$} & Temp & -ve & 14.28 & 0.0002 & \multirow[t]{4}{*}{0.62} & \multirow[t]{4}{*}{0.50} \\
\hline & Sex & $\mathrm{F}>\mathrm{M}$ & 47.35 & $<0.0001$ & & \\
\hline & Protein & +ve & 291.4 & $<0.0001$ & & \\
\hline & Sex $\times$ Protein & F more +ve & 56.10 & $<0.0001$ & & \\
\hline $\mathrm{Sr}_{\mathrm{B}}$ & Sex & & 0.079 & ns & 0.51 & 0.23 \\
\hline & Growth rate & -ve (not in F-only model) & 19.17 & $<0.0001$ & & \\
\hline & Protein & + ve & 49.21 & $<0.0001$ & & \\
\hline & Sex $\times$ Protein & +ve $F_{1}$-ve $M$ & 66.38 & $<0.0001$ & & \\
\hline & GSI (F only) & +ve & 25.85 & $<0.0001$ & 0.66 & 0.40 \\
\hline $\mathrm{Ba}_{\mathrm{B}}$ & $\mathrm{Ba} / \mathrm{Ca}_{\mathrm{W}}$ & & 0.363 & ns & 0.18 & 0.18 \\
\hline & Temp & & 0.475 & ns & & \\
\hline & $\mathrm{Ba} / \mathrm{Ca}_{\mathrm{W}} \times \mathrm{Temp}$ & ns at $\downarrow$ Temp, +ve at $\uparrow$ Temp & 21.95 & $<0.0001$ & & \\
\hline $\mathrm{Mn}_{\mathrm{B}}$ & Sex & $\mathrm{F}>\mathrm{M}$ & 10.35 & 0.0010 & 0.43 & 0.20 \\
\hline & Growth rate & +ve & 8.93 & 0.0030 & & \\
\hline & Condition & + ve & 27.55 & $<0.0001$ & & \\
\hline $\mathrm{Cu}_{\mathrm{B}}$ & Protein & +ve & 56.83 & $<0.0001$ & 0.61 & 0.42 \\
\hline & Condition & +ve & 21.88 & $<0.0001$ & & \\
\hline & Temp & +ve & 25.92 & $<0.0001$ & & \\
\hline & Sex & $M>F$ & 7.40 & 0.0065 & & \\
\hline & Temp $\times$ Sex & +ve $F,-$ ve $M$ & 30.02 & $<0.0001$ & & \\
\hline & GSI (F only) & -ve & 16.54 & $<0.0001$ & 0.60 & 0.47 \\
\hline $\mathrm{Zn}_{\mathrm{B}}$ & Temp & +ve & 67.93 & $<0.0001$ & 0.76 & 0.63 \\
\hline & Protein & + ve & 47.34 & $<0.0001$ & & \\
\hline & Condition & -ve & 15.82 & $<0.0001$ & & \\
\hline & GSI (F only) & -ve & 9.45 & $<0.0001$ & 0.74 & 0.66 \\
\hline $\mathrm{Se}_{\mathrm{B}}$ & Origin & IS $>$ EC & 33.48 & $<0.0001$ & 0.71 & 0.42 \\
\hline & Sex & $M>F$ & 11.58 & 0.0007 & & \\
\hline & Protein & +ve & 62.97 & $<0.0001$ & & \\
\hline & $\mathrm{Se}_{\mathrm{W}}$ & +ve & 59.38 & $<0.0001$ & & \\
\hline & GSI (F only) & -ve & 15.27 & $<0.0001$ & 0.71 & 0.44 \\
\hline $\mathrm{Pb}_{\mathrm{B}}$ & Condition & (not in F-only model) & 0.507 & ns & 0.34 & 0.23 \\
\hline & Sex & $F>M$ & 7.93 & 0.0049 & & \\
\hline & Growth rate & +ve & 7.73 & 0.0054 & & \\
\hline & Protein & +ve & 11.32 & 0.0008 & & \\
\hline & Condition $\times$ Sex & +ve $F_{1}$-ve M & 44.85 & $<0.0001$ & & \\
\hline & GSI (F only) & -ve & 9.84 & 0.0017 & 0.40 & 0.26 \\
\hline
\end{tabular}

\section{Potassium and rubidium}

$\mathrm{K}_{\mathrm{B}}$ and $\mathrm{Rb}_{\mathrm{B}}$ values displayed similar behaviours over time (Fig. $4 \mathrm{~b}, \mathrm{c})$. Unlike most other elements, initial and terminal $K_{B}$ and $\mathrm{Rb}_{\mathrm{B}}$ values were different because of an overall decline, and they were best explained by sampling date $(\mathrm{p}<0.001)$. There was no overall difference in $\mathrm{K}_{\mathrm{B}}$ and $\mathrm{Rb}_{\mathrm{B}}$ values between the sexes, although there was a dip in $K_{B}$ around November in the IS females and a dip in $\mathrm{K}_{\mathrm{B}}$ and $\mathrm{Rb}_{\mathrm{B}}$ in Jan- 
uary in the males. Negative relationships between $K_{B}$ and $\mathrm{Rb}_{\mathrm{B}}$ values and plasma protein concentrations were observed $(p<0.01)$, and $K_{B}$ values were also partly explained by a negative effect of temperature $(p=0.02)$. Similar to $\mathrm{Li}_{\mathrm{B}}$, there was a positive relationship between $K_{B}$ and $\mathrm{Rb}_{\mathrm{B}}$ values and salinity, but it was not significant. Model fits were weak to moderate $\left(r^{2}>0.20\right)$, with little variation explained by the random effect.

\section{Magnesium}

$\mathrm{Mg}_{\mathrm{B}}$ values varied in a roughly sinusoidal manner, peaking from September to January and falling in the winter spawning season (Fig. 4d). Concentrations were primarily explained by salinity $(p<0.001)$ and plasma protein concentrations ( $p<0.001)$, but unlike the monovalent ions discussed above, $\mathrm{Mg}_{\mathrm{B}}$ values were positively associated with protein levels. There was also a weak effect of GnRH treatment ( $p=0.03)$, with higher $\mathrm{Mg}_{\mathrm{B}}$ values observed in treated fish, although it was not significant in the female-only model. Model fits were relatively poor $\left(\mathrm{r}^{2}=0.17\right.$ to 0.21), with little variation explained by the random effect.
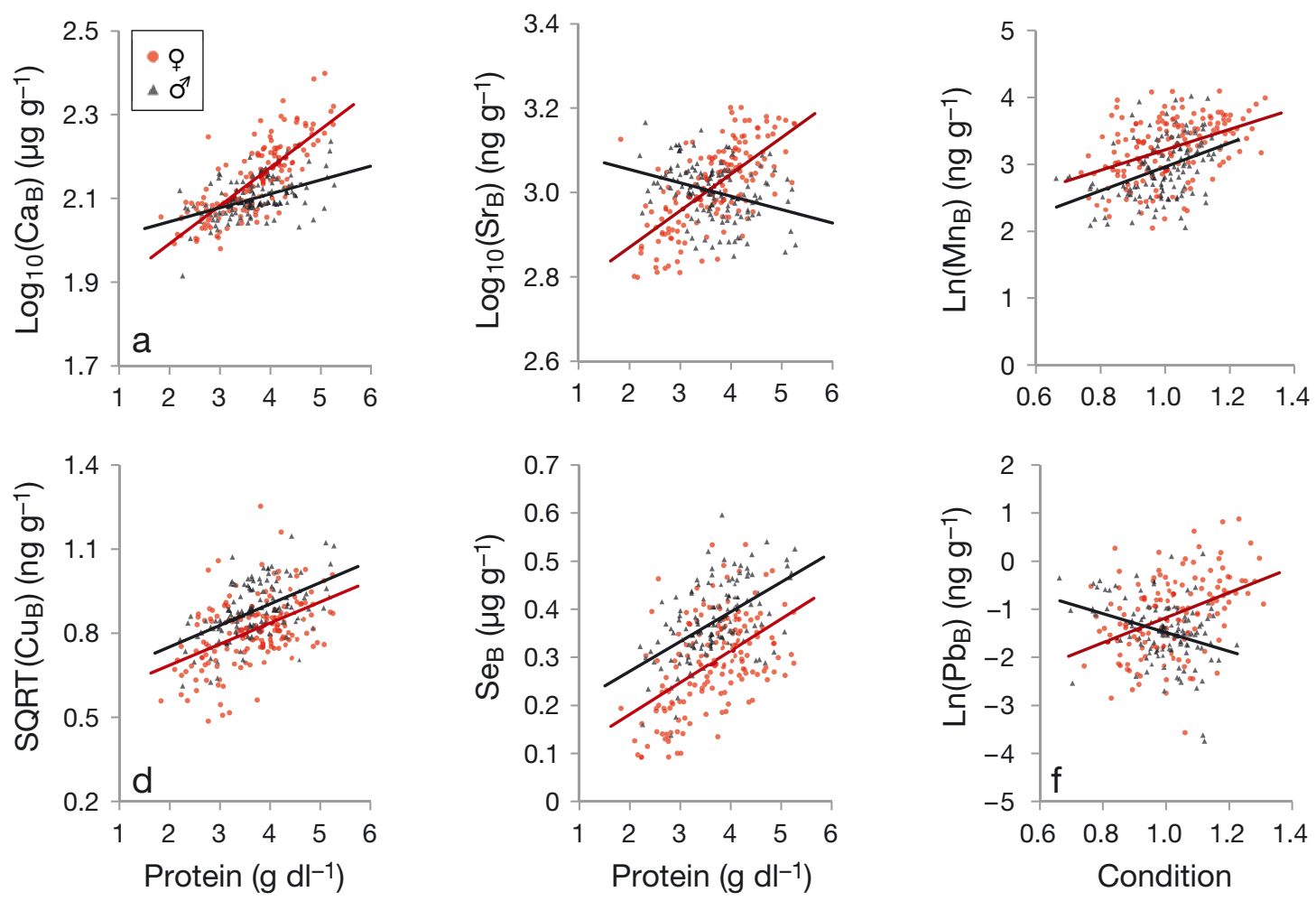

Fig. 5. Plots to show the strongest relationships explaining blood plasma elemental concentrations in 25 male ( $\left.0^{7}\right)$ and female (o) plaice serially sampled for 7 to $12 \mathrm{mo}(\mathrm{n}=282)$. Data were transformed where required to meet linear mixed-effects model

\section{Calcium and strontium}

$\mathrm{Ca}_{\mathrm{B}}$ and $\mathrm{Sr}_{\mathrm{B}}$ values exhibited similar trends over time (Fig. 4e,f). Unlike the other Group II metals, Ca and $\mathrm{Sr}_{\mathrm{B}}$ values exhibited clear differences between groups of fish, although initial and terminal concentrations were similar. $\mathrm{Ca}_{\mathrm{B}}$ and $\mathrm{Sr}_{\mathrm{B}}$ values peaked in the IS females during winter; however, the timing of the peak was slightly asynchronous (December and February, respectively). Accordingly, the $\mathrm{Ca}_{\mathrm{B}}$ model included a negative effect of temperature $(p<0.001)$, but the $\mathrm{Sr}_{\mathrm{B}}$ model did not. Concentrations of both elements were largely explained by an overall positive relationship with plasma protein concentrations $(\mathrm{p}<$ 0.001); however, the nature of this relationship differed between the sexes. The slope of the relationship was steeper in the females, particularly for $\mathrm{Sr}_{\mathrm{B}}$, which was negatively correlated with plasma protein concentrations in the males (Fig. 5a,b). $\mathrm{Sr}_{\mathrm{B}}$ values were negatively related to somatic growth rate $(\mathrm{p}<$ 0.001 ) and positively related to GSI in the females ( $p$ $<0.001$, Fig. 6a). Model fits were good for both elements $\left(\mathrm{r}^{2}>0.5\right)$ and better for the female-only models. Approximately 10 and $30 \%$ of the variance was explained by the random effect for $\mathrm{Ca}_{\mathrm{B}}$ and $\mathrm{Sr}_{\mathrm{B}}$, respectively, indicating some among-fish differences

\footnotetext{
assumptions. SQRT = square root
} 

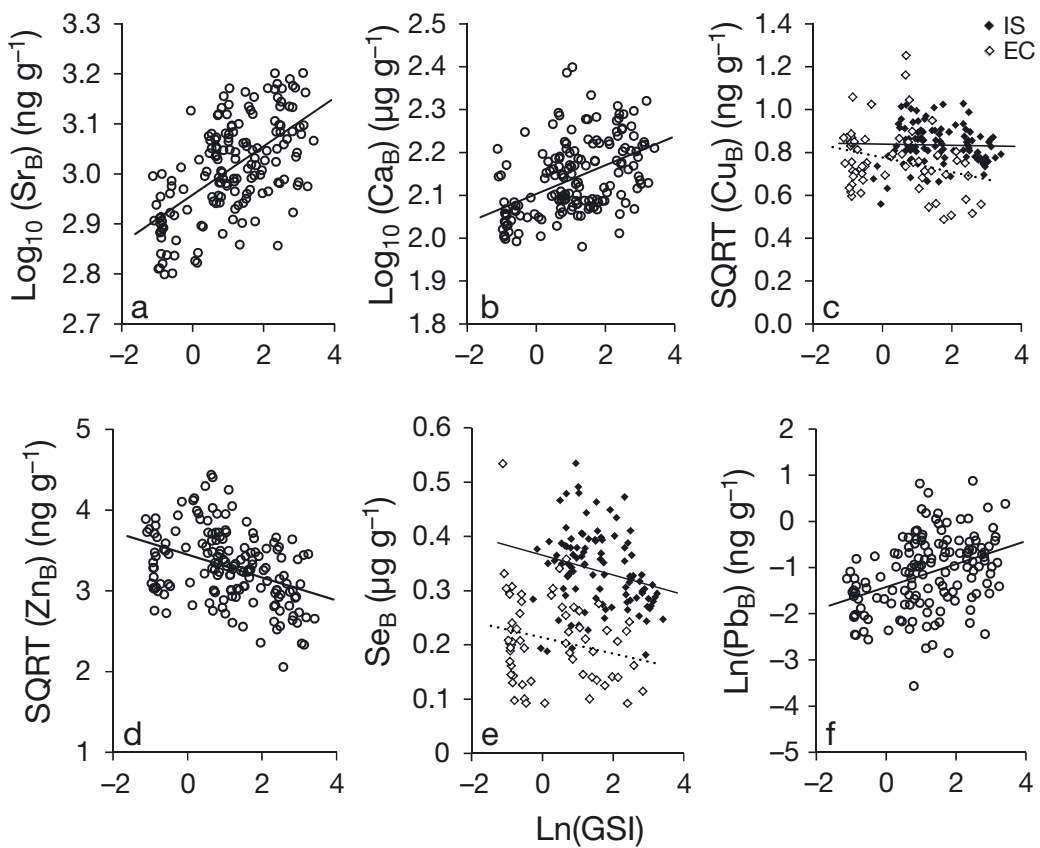

Fig. 6. Relationships between estimated gonadosomatic index (GSI) and blood plasma elemental concentrations in 15 female plaice from the Irish Sea $(\mathrm{IS}, \bullet)$ and English Channel (EC, o) serially sampled for 7 to $12 \mathrm{mo}(\mathrm{n}=162)$. Different responses exhibited by IS and EC fish are indicated by solid and dashed lines, respectively. Note that the displayed relationships were not necessarily included in the final models. SQRT $=$ square root

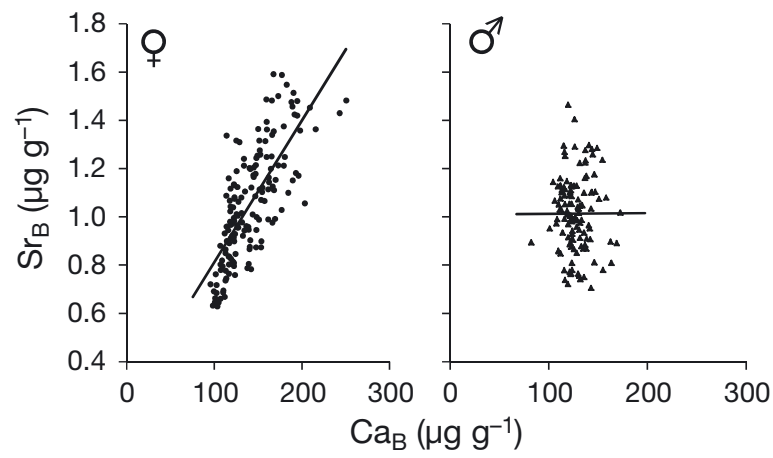

Fig. 7. Paired plot to show the relationship between $\mathrm{Ca}_{\mathrm{B}}$ and $\mathrm{Sr}_{\mathrm{B}}$ values in male $\left({ }^{\prime}\right)$ and female (o) plaice

not explained by the fixed effects. The similar trends in $\mathrm{Ca}_{\mathrm{B}}$ and $\mathrm{Sr}_{\mathrm{B}}$ values over time were reflected in a strong positive correlation in the females, but there was no analogous relationship observed in the males (Fig. 7).

\section{Barium}

There were no differences in $\mathrm{Ba}_{\mathrm{B}}$ values between the groups of fish and limited temporal variability, except for a dip in December that was exhibited by all groups of fish (Fig. 4g). Unlike the other elements, $\mathrm{Ba}_{\mathrm{B}}$ values were more strongly correlated with $\mathrm{Ba} / \mathrm{Ca}_{\mathrm{W}}$ ratios than Baw. However, even with the marginal improvement obtained using $\mathrm{Ba} / \mathrm{Ca}_{\mathrm{W}}$, model performance was poor $\left(\mathrm{r}^{2}=0.18\right.$ to 0.27$)$, with no variation explained by the random effect. The interaction between $\mathrm{Ba} / \mathrm{Ca}_{\mathrm{w}}$ values and temperature suggested a weakly positive effect of $\mathrm{Ba} / \mathrm{Ca}_{\mathrm{W}}$ on $\mathrm{Ba}_{\mathrm{B}}$ values at higher temperatures but no effect at lower temperatures.

\section{Manganese}

$\mathrm{Mn}_{\mathrm{B}}$ values were lowest at the start and end of the experimental period and exhibited small peaks in July and November (Fig. $4 \mathrm{~h}$ ). $\mathrm{Mn}_{\mathrm{B}}$ values were higher in females $(p=0.001)$, and variations in $\mathrm{Mn}_{\mathrm{B}}$ values were mainly explained by a positive effect of condition ( $\mathrm{p}<0.001$, Fig. 5c) and growth rate $(\mathrm{p}<0.031)$. Model fit was moderate $\left(\mathrm{r}^{2}=\right.$ 0.30 to 0.43 ), divided almost equally between the fixed and random effects.

\section{Copper}

For most individuals, $\mathrm{Cu}_{\mathrm{B}}$ values peaked in early winter and then fell rapidly through the spawning season before increasing towards the end of the experiment (Fig. 4i). The males exhibited higher $\mathrm{Cu}_{B}$ values $(\mathrm{p}<0.01)$, and while the EC females exhibited consistently lower concentrations than the IS fish, this was explained by condition and plasma protein concentrations rather than 'origin'. Inferring the main controls on $\mathrm{Cu}_{\mathrm{B}}$ values was more complex than for most other elements, as concentrations were correlated with many of the covariates. However, all candidate models contained a main positive effect of plasma protein concentrations, particularly in the females (Fig. $5 \mathrm{~d}$ ). $\mathrm{Cu}_{\mathrm{W}}$ values and temperature were highly correlated $(r=0.95)$, so it was impossible to discriminate their effects. The best model included a significant interaction between $\mathrm{Cu}_{\mathrm{W}}$ and origin, with $\mathrm{EC}$ females exhibiting positive relationships between plasma and ambient concentrations and IS fish exhibiting no relationship. While this interaction explained an additional $5 \%$ of the variation, it was ex- 
cluded from the final model, given the lack of equivalent 'high $\mathrm{Cu}_{\mathrm{W}}$ values' represented in the EC females because of their delayed introduction to the experiment. The final model included a significant interaction between sex and temperature $(p<0.001)$ resulting from a positive relationship between $\mathrm{Cu}_{\mathrm{B}}$ values and temperature in the females and a weakly negative relationship in the males. The female-only model also included a negative effect of GSI that was most apparent in the EC females (Fig. 6c), but while the interaction between origin and GSI was significant $(p=0.02)$, it did not improve model fit (AIC or $\left.\mathrm{r}^{2}\right)$ and so was not included. Overall model fits were good $\left(r^{2}>0.6\right)$, with 13 to $19 \%$ of the variance explained by the random effect.

\section{Zinc}

$\mathrm{Zn}_{\mathrm{B}}$ values decreased during the spawning season in all fish but had returned to initial levels by the end of the experiment (Fig. 4j). Concentrations were primarily explained by a positive relationship with ambient concentrations or temperature. Inclusion of either term produced $\mathrm{r}^{2}$ values $>0.7$, with most of the variance explained by the fixed effects. Model fits were marginally higher (1 to $5 \%$ ) using $\mathrm{Zn}_{\mathrm{W}}$ values over temperature; however, given lower confidence in $\mathrm{Zn}_{\mathrm{W}}$ measurements (see 'Methods'), temperature was selected for the final model. In both models, plasma protein concentrations and condition also contributed significantly to the model fit, acting in opposite directions. During the spawning season, $\mathrm{Zn}_{\mathrm{B}}$ values were lower in the females, particularly the IS females, and in the female-only model, the negative effect of GSI was highly significant (Fig. 6d). Model fits were good $\left(\mathrm{r}^{2}>0.7\right)$, with only 8 to $13 \%$ of the variation explained by the random effect.

\section{Selenium}

$\mathrm{Se}_{\mathrm{B}}$ values exhibited a similar sinusoidal pattern to $\mathrm{Cu}_{\mathrm{B}}$ values, peaking just before the spawning season, decreasing from January through March and then increasing towards the end of the experiment (Fig. 4k). Unlike most other elements, initial and terminal Se concentrations differed, with terminal concentrations higher in all groups of fish. There were clear differences in $\mathrm{Se}_{\mathrm{B}}$ values between groups, with lower $\mathrm{Se}_{\mathrm{B}}$ values in the EC fish $(\mathrm{p}<$ $0.001)$ and the females $(p<0.001)$. $\mathrm{Se}_{B}$ values were largely explained by plasma protein and ambient water concentrations. Substituting temperature for $\mathrm{Se}_{\mathrm{W}}$ reduced model fit by $\sim 10 \%$. Similar to $\mathrm{Zn}_{\mathrm{B}}$ and $\mathrm{Cu}_{\mathrm{B}}$, a significant negative effect of GSI was found in the female-only model (Fig. 6e). Overall model fits were good $\left(\mathrm{r}^{2}>0.7\right)$, with the random effect explaining almost $30 \%$ of the variation.

Lead

While individual measurements were more variable, $\mathrm{Pb}_{\mathrm{B}}$ behaved in a broadly similar manner to $\mathrm{Ca}_{\mathrm{B}}$ and $\mathrm{Sr}_{\mathrm{B}}$. Concentrations peaked in December in the IS females and, apart from a small peak in the EC females at the start of the spawning season, remained relatively constant in the males and EC females (Fig. 41). The most important predictor of $\mathrm{Pb}_{\mathrm{B}}$ values was an interaction between condition and sex, with a positive relationship between condition and $\mathrm{Pb}_{\mathrm{B}}$ values in the females but a negative relationship in the males (Fig. 5f). Unlike $\mathrm{Sr}_{\mathrm{B}}, \mathrm{Pb}_{\mathrm{B}}$ values were positively correlated with growth rate. Similar to $\mathrm{Ca}_{\mathrm{B}}$ and $\mathrm{Sr}_{\mathrm{B}}, \mathrm{Pb}_{\mathrm{B}}$ values were positively related to plasma protein concentrations $(p<0.01)$ and were higher in the females $(p=0.005)$. The female-only model included GSI instead of condition (Fig. 6f) and exhibited a slightly better fit $\left(\mathrm{r}^{2}=0.40\right.$ vs. 0.34$)$.

\section{Correlations with ambient concentrations}

Pairwise correlations were carried out between blood plasma and water concentrations for each element (Table 4). The strongest positive relationships were observed for $\mathrm{Zn}, \mathrm{Se}, \mathrm{Li}, \mathrm{Rb}$ and $\mathrm{Mg}$, while $\mathrm{Ca}$, $\mathrm{Sr}$ and $\mathrm{Ba}$ concentrations were either uncorrelated or negatively correlated between blood plasma and water. Two elements exhibited contradictory patterns among subject groups: $\mathrm{Cu}_{\mathrm{W}}$ was positively correlated with $\mathrm{Cu}_{\mathrm{B}}$ in the $\mathrm{EC}$ females and negatively correlated in the males, while $\mathrm{Pb}_{\mathrm{W}}$ was positively correlated with $\mathrm{Pb}_{\mathrm{B}}$ in the males and negatively correlated in the IS females.

\section{Distribution coefficients}

Blood plasma-to-water distribution coefficients $\left(D_{\mathrm{El}}(\mathrm{B} / \mathrm{W})\right.$ of the 12 elements varied by more than 5 orders of magnitude, ranging from $0.01\left(\mathrm{D}_{\mathrm{Rb}(\mathrm{B} / \mathrm{W})}\right)$ to $>8500\left(\mathrm{D}_{\mathrm{Se}(\mathrm{B} / \mathrm{W})}\right)$. Coefficients were $>1$ for all 'soft' elements, indicating enrichment of the blood plasma relative to ambient concentrations. For Group I and II 
Table 4. Correlation coefficients (r) for the relationship between blood plasma vs. water elemental concentrations and average distribution coefficients $\left(D_{\mathrm{El}}(\mathrm{B} / \mathrm{W})\right.$ ) from the current study and reported in Melancon et al. (2009) for 2 freshwater fish species. Here, monthly blood samples were collected from 25 fish from the Irish Sea (IS) and English Channel (EC) and related to water concentrations predicted for specific blood sampling days by local polynomial regression fitting (LOESS) smoothers (Fig. 3). Weaker correlations, (r-values between -0.2 and 0.2 ) are shaded in grey. na = not available

\begin{tabular}{|c|c|c|c|c|c|c|}
\hline & \multicolumn{3}{|c|}{$\longrightarrow \mathrm{r}\left(\mathrm{El}_{\mathrm{B}}\right.$ vs. $\left.E l_{\mathrm{W}}\right)$} & \multirow{3}{*}{$\begin{array}{c}\text { Present study } \\
\text { Pleuronectes } \\
\text { platessa }\end{array}$} & \multirow{2}{*}{\multicolumn{2}{|c|}{$\begin{array}{l}\mathrm{D}_{\mathrm{El}(\mathrm{B} / \mathrm{W})} \\
\text { Melancon et al. (2009) }\end{array}$}} \\
\hline & IS Males & IS & $\mathrm{EC}$ & & & \\
\hline & $(\mathrm{n}=120)$ & $\begin{array}{l}\text { females } \\
(\mathrm{n}=102)\end{array}$ & $\begin{array}{l}\text { females } \\
(\mathrm{n}=60)\end{array}$ & & $\begin{array}{l}\text { Lota } \\
\text { lota }\end{array}$ & $\begin{array}{l}\text { Salvelinus } \\
\text { namaycush }\end{array}$ \\
\hline $\mathrm{Li}$ & 0.37 & 0.21 & 0.35 & 0.423 & na & na \\
\hline $\mathrm{K}$ & 0.31 & 0.06 & 0.12 & 0.140 & 1560 & 1590 \\
\hline $\mathrm{Rb}$ & 0.40 & 0.23 & 0.12 & 0.061 & 2590 & 3190 \\
\hline $\mathrm{Mg}$ & 0.19 & 0.26 & 0.38 & 0.024 & 10.2 & 10.4 \\
\hline $\mathrm{Ca}$ & -0.05 & -0.24 & -0.06 & 0.391 & 3.03 & 3.85 \\
\hline $\mathrm{Sr}$ & 0.07 & -0.32 & -0.25 & 0.165 & 1.63 & 1.07 \\
\hline $\mathrm{Ba}$ & 0.08 & -0.15 & -0.25 & 0.684 & 20.0 & 13.7 \\
\hline $\mathrm{Mn}$ & -0.16 & -0.03 & -0.09 & 41.38 & 161 & 197 \\
\hline $\mathrm{Cu}$ & -0.25 & -0.04 & 0.46 & 142.8 & na & na \\
\hline $\mathrm{Zn}$ & 0.32 & 0.57 & 0.44 & 3363 & 4790 & 7250 \\
\hline $\mathrm{Se}$ & 0.34 & 0.55 & 0.26 & 5214 & na & na \\
\hline $\mathrm{Pb}$ & 0.29 & -0.21 & -0.03 & 2.836 & 500 & 1490 \\
\hline
\end{tabular}

elements, average $\mathrm{D}_{\mathrm{El}(\mathrm{B} / \mathrm{W})}$ values were consistently $<1$ (Table 4), but individual $\mathrm{D}_{\mathrm{Ba}(\mathrm{B} / \mathrm{W})}$ values were occasionally $>1$, particularly during winter. There were substantial differences between $\mathrm{D}_{\mathrm{El}(\mathrm{B} / \mathrm{W})}$ values from this study and those reported by Melancon et al. (2009) for 2 freshwater species (Table 4). Differences were expected for the conservative elements (e.g. $\mathrm{D}_{\mathrm{K}(\mathrm{B} / \mathrm{W})}$ and $\mathrm{D}_{\mathrm{Rb}(\mathrm{B} / \mathrm{W})}$ ) because of contrasting environmental concentrations, but differences among some of the other elements may have reflected variation in environmental or dietary concentrations, fluid type (whole blood vs. plasma) and/or sample treatment (Sturrock et al. 2013).

\section{DISCUSSION}

Fish blood plasma represents the major fluid medium that ions pass through during their transport between the environment and the otolith. To understand element incorporation into the otolith, it is therefore important to appreciate transport and fractionation of elements between ambient water and the blood. Clearly, blood plasma is highly regulated, and its elemental composition reflects environmental conditions as well as the physiological and nutritional status of the fish. Most applications of otolith microchemistry assume that differences in trace element concentrations between individuals and within otoliths reflect exposure to differing ambient concentrations. Here, elemental concentrations were rarely correlated between the blood plasma and ambient seawater, setting a first order limit on the sensitivity of otolith chemistry to environmental fluctuations. Variations in plasma microchemistry over time and between our 3 groups (IS males, IS females and EC females) demonstrated that physiological influences could outweigh environmental signals in a fully marine setting. These influences were more pronounced for the softer, thiophilic elements ( $\mathrm{Mn}, \mathrm{Cu}$, $\mathrm{Zn}, \mathrm{Se}$ and $\mathrm{Pb}$ ) and the quasi-conservative elements (Sr and $\mathrm{Ca}$ ). Apart from $\mathrm{Sr}$ and $\mathrm{Ca}$, the hard acid metal ions $\left(\mathrm{Li}^{+}, \mathrm{Mg}^{2+}, \mathrm{K}^{+}, \mathrm{Rb}^{+}, \mathrm{Ba}^{2+}\right)$ were less affected by physiology, with reduced temporal variation and only minor differences in $\mathrm{Li}_{\mathrm{B}}$ observed between the sexes. Overall, plasma protein concentration had the strongest influence on elemental concentrations and was included in nearly all of the predictive models. Aside from $\mathrm{Li}_{\mathrm{B}}, \mathrm{Ba}_{\mathrm{B}}, \mathrm{K}_{\mathrm{B}}$ and $\mathrm{Rb}_{\mathrm{B}}$, elemental concentrations were consistently positively related to protein concentrations in the blood plasma. These results emphasise the importance of protein-metal binding in the regulation of plasma elemental concentrations, with many physiological variables having the potential to influence blood chemistry via modifications to protein composition and abundance (Kalish 1991). Future work to characterise how ions occur in both water and biological fluids (free, ligand complexes, protein bound and/or associated with particulates) will provide further insight into their availability to the various tissues.

In wild plaice, growth rate is usually negatively correlated with age (Fonds et al. 1992), yet the younger EC females generally exhibited lower condition, growth rates and GSI (Fig. 1a,b,d), and lower protein, $\mathrm{Cu}$ and $\mathrm{Se}$ concentrations in the blood plasma (Figs. 1c \& 4j,k). Intrinsic differences were considered unlikely, as the 2 stocks are genetically indistinct (Hoarau et al. 2004, Watts et al. 2004). However, the lagged introduction of the EC females did coincide with falling water temperatures (Fig. 2), which may have increased stress in this group of fish. As plaice stop feeding in winter, even in the presence of food (Rijnsdorp 1990), such elevated stress could have also triggered premature reduction in feeding 
activity. Stress can modify fish condition and blood chemistry, and may have caused the elevated $K_{B}$ values observed in all groups of fish during initial sampling months, with the gradual decrease representing habituation over time (Waring et al. 1992, 1996). While stress was not formally measured, it is reassuring that growth rates, condition and GSI of the subject animals were comparable to wild populations (Rijnsdorp 1989, Maddock \& Burton 1998, Bromley 2000) and that plasma elemental concentrations were broadly similar to those reported in the literature, where available (Sturrock et al. 2013).

It is important to acknowledge the limitations of 'mensurative experiments' (Hurlbert 1984) such as these, where attempts to reproduce natural conditions yield inherent complexity. Formal hypothesis testing is compromised; however, even in controlled laboratory settings, the separation of correlated effects such as growth rate and temperature can still prove challenging (e.g. Walther et al. 2010). Here, many variables covaried on a seasonal basis, particularly salinity, water elemental concentrations and temperature. Retaining a natural temperature cycle was necessary to stimulate gonad development, and while maintenance of constant water chemistry would have been preferable, the cost for such a longterm experiment would have been prohibitive. AICbased model selection provided a means to nonsubjectively reduce collinearity; however, this inherent limitation, along with the potential for biological lags (e.g. Macdonald \& Crook 2010), means that further experimental work is advised to confirm the importance of (and mechanisms governing) the selected model terms. Whatever the underlying processes, we have shown clear differences in plasma elemental concentrations between individuals and groups of fish living in common marine conditions. Here, we discuss the main results in the context of 3 areas we believe have the greatest relevance in the field of otolith microchemistry: (1) growth and condition, (2) sex and reproduction, and (3) environmental effects.

\section{Growth and condition}

Plaice growth and condition vary as a function of feeding, temperature, photoperiod and age (Rijnsdorp 1990, Fonds et al. 1992, Bromley 2000). In our experiment, the plasma elemental concentrations that were significantly affected by growth rate and/or condition included $\mathrm{Sr}$ and most of the soft, thiophilic elements ( $\mathrm{Mn}, \mathrm{Cu}, \mathrm{Zn}$ and $\mathrm{Pb}$ ).
The concentration of Sr in blood plasma was negatively related to growth rate, consistent with field observations relating otolith $\mathrm{Sr} / \mathrm{Ca}$ ratios in marine fish with seasonal and ontogenetic changes in growth rate, despite essentially uniform ambient concentrations (Kalish 1989, Sadovy \& Severin 1994, Brown \& Severin 2009). Growth rate was not included in the female-only model, however, and in other studies, relationships between growth rate and otolith $\mathrm{Sr} / \mathrm{Ca}$ ratios are not always detected, implying sex-, species- and/or stage-specific processes (Walther et al. 2010). Other studies have hypothesised that temperature is the primary driver of apparent growth rate effects (e.g. Martin et al. 2004), but here, temperature was uncorrelated with growth rate $(\mathrm{r}=-0.05)$.

Growth rate had a significant positive influence on $\mathrm{Mn}$ and $\mathrm{Pb}$ concentrations in blood plasma. Based on previous experimental work, it is likely that soft acid metal ions such as $\mathrm{Mn}, \mathrm{Zn}$ and $\mathrm{Cu}$ are largely protein bound in the blood (e.g. Fletcher \& Fletcher 1980), and a significant proportion may be sourced from the diet (e.g. Pentreath 1973, 1976, Ranaldi \& Gagnon 2008). Indeed, plasma concentrations of all soft elements were enriched relative to ambient concentrations, exhibiting average distribution coefficients as high as $3363\left(\mathrm{D}_{\mathrm{Zn}(\mathrm{B} / \mathrm{w})}\right)$. Protein-metal binding in the blood influences the rate of elemental turnover and exerts a major influence on the proportion of dissolved free ions and their ability to pass across membranes via passive or active mechanisms. While most proteins are unlikely to move freely from blood to endolymph, some proteins and free amino acids form the precursor molecules for the otolith organic matrix (Payan et al. 2004b). Thus, even predominantly 'bound' ions may still enter the endolymph and become incorporated into the otolith crystal lattice or organic matrix. If $\mathrm{Mn}_{\mathrm{B}}$ and $\mathrm{Pb}_{\mathrm{B}}$ are indeed primarily sourced from the diet, this could explain the positive growth rate effect on blood concentrations (Table 3), given that growth is primarily a function of food ration (Fonds et al. 1992) and concentrations of both elements were orders of magnitude higher in the diet than the ambient seawater (M. J. Cooper unpubl.). Such effects might be especially pronounced in our study, given that most $(75 \%)$ subject animals were selected on the basis of greater otolith deposition during the experimental period, which was generally accompanied by faster somatic growth rates. However, $\mathrm{Mn}_{\mathrm{B}}$ values remained enriched through the non-feeding period (January through March), implying additional waterborne sources or recycling via tissue breakdown or bone demineralisation (e.g. Kacem et al. 2000). 


\section{Sex and reproduction}

Sex and/or GSI significantly influenced blood plasma concentrations of all elements except $\mathrm{K}, \mathrm{Rb}$, $\mathrm{Mg}$ and $\mathrm{Ba}$. Overall, $\mathrm{Li}_{\mathrm{B}}, \mathrm{Ca}_{\mathrm{B}}, \mathrm{Mn}_{\mathrm{B}}$ and $\mathrm{Pb}_{\mathrm{B}}$ values were higher in females, while $\mathrm{Cu}_{\mathrm{B}}$ and $\mathrm{Se}_{\mathrm{B}}$ values were higher in males. For some elements $(\mathrm{Cu}, \mathrm{Pb}, \mathrm{Ca}$ and Sr), sex interacted with other covariates, further complicating relationships between tissue and ambient concentrations. Excluding the quasi-conservative elements ( $\mathrm{Sr}$ and $\mathrm{Ca}$ ), Li was the only hard element to exhibit sex-related differences in plasma concentrations; however, the difference was relatively small. Given that $\mathrm{Li}_{\mathrm{B}}$ values were similar in the mature and immature females, this sex effect is unlikely to be explained by ovary development but may reflect differences in size and growth typical of this sexually dimorphic species (Rijnsdorp 1989).

Unlike the other elements that form hard acid ions, $\mathrm{Ca}_{\mathrm{B}}$ and $\mathrm{Sr}_{\mathrm{B}}$ values exhibited significant differences between males and females during the reproductive season (Fig. 4e,f). In the females, almost $60 \%$ of the variation in $\mathrm{Ca}_{\mathrm{B}}$ was explained by plasma protein concentrations, while $40 \%$ of the variation in $\mathrm{Sr}_{\mathrm{B}}$ was explained by protein concentrations and GSI. These observations support previous findings that total plasma Ca concentrations (and probably Ca homologues such as Sr) are divided approximately equally between bound and unbound fractions (Mugiya 1966, Andreasen 1985). Relationships between blood hypercalcaemia, hyperproteinaemia and reproductive investment in oviparous fish are well recognised, with females mobilising large quantities of protein and $\mathrm{Ca}^{2+}$ for egg production (Urist \& Schjeide 1961). Spawning-related increases in $\mathrm{Ca}_{\mathrm{B}}$ values have been reported for a range of marine, euryhaline and freshwater species (e.g. Woodhead 1968, Shearer 1984, Valtonen \& Laitinen 1988). In North Sea plaice, ovaries begin to grow in mass from October (Rijnsdorp 1989), coinciding with the observed increase in $\mathrm{Ca}_{\mathrm{B}}$ in the IS females. In plaice, female reproductive investment is approximately twice that of males (Bromley 2000), and while hypercalcaemia was most extreme in the mature females, it was also detectable in the immature females and males, an observation shared by some other studies (Kalish 1991, Folmar et al. 1992). The mechanisms governing these patterns remain unclear, but possible explanations include increased recovery of $\mathrm{Ca}^{2+}$ through the gut lining, increased residence time of protein-bound Ca compared to free $\mathrm{Ca}^{2+}$ (Williams 1971) and/or demineralisation of bones and breakdown of soft tissues during starvation periods (Kacem et al. 2000).
The relationships between plasma protein concentrations (or condition) and $\mathrm{Ca}_{\mathrm{B}}, \mathrm{Sr}_{\mathrm{B}}$ and $\mathrm{Pb}_{\mathrm{B}}$ differed markedly between the males and females, particularly for $\mathrm{Sr}_{\mathrm{B}}$ and $\mathrm{Pb}_{\mathrm{B}}$ (Fig. 5a,b,f). These patterns appeared to be driven by increased plasma elemental concentrations relating to ovary development, as indicated by positive correlations with GSI (Fig. 6a,b,f). Similar patterns were observed by Kalish (1991) and are corroborated by seasonal trends in ovary Ca and Sr concentrations in rainbow trout (Shearer 1984). In mature females, the period of hypercalcaemia is accompanied by synthesis of proteins and steroids specific to oocyte production and maturation (Scott et al. 1998). Differences in their binding capacity and specificity may explain the sex-specific interactions observed for $\mathrm{Sr}_{\mathrm{B}}, \mathrm{Ca}_{\mathrm{B}}$ and $\mathrm{Pb}_{\mathrm{B}}$ and may, in turn, affect ion availability to the otolith.

Shearer (1984) postulated that the positive correlation between GSI and ovary Sr concentrations indicated a functional requirement of $\mathrm{Sr}_{\mathrm{B}}$ to transfer $\mathrm{Ca}_{\mathrm{B}}$ to the ovaries. However, $\mathrm{Sr}$ is otherwise considered to be a 'nonessential' element (Underwood 1977), and $\mathrm{Pb}$ is well documented for its toxicity in fish (e.g. Martinez et al. 2004). The concomitant increases in $\mathrm{Ca}_{\mathrm{B}}, \mathrm{Sr}_{\mathrm{B}}$ and $\mathrm{Pb}_{\mathrm{B}}$ in maturing females may simply reflect increased protein and $\mathrm{Ca}$ requirements for egg production (Urist \& Schjeide 1961) and chemical similarities between $\mathrm{Sr}^{2+}, \mathrm{Pb}^{2+}$ and $\mathrm{Ca}^{2+}$ ions. The lagged peak in $\mathrm{Sr}_{\mathrm{B}}$ and $\mathrm{Pb}_{\mathrm{B}}$ compared to $\mathrm{Ca}_{\mathrm{B}}$ may reflect preferential removal of $\mathrm{Ca}^{2+}$ for egg production and/or changes in uptake mechanisms and sources during the spawning season. In mature female plaice, $64 \%$ of carcass lipids are broken down to meet the majority of metabolic energy requirements during the starvation period, and $40 \%$ of carcass proteins are metabolised primarily for egg production (Dawson \& Grimm 1980). Element-specific partitioning among tissue types and sex-specific differences in tissue metabolism during the non-feeding period may explain the differences among the sexes and temporal asynchrony among the elements.

Unlike $\mathrm{Sr}_{\mathrm{B}}$ and $\mathrm{Pb}_{\mathrm{B}}, \mathrm{Cu}_{\mathrm{B}}, \mathrm{Zn}_{\mathrm{B}}$ and $\mathrm{Se}_{\mathrm{B}}$ generally decreased during the spawning season, particularly in the mature IS females. Plasma concentrations were partly explained by a negative relationship with GSI (Fig. 6c,d,e), presumably reflecting their removal for egg production. $\mathrm{Cu}$ and $\mathrm{Zn}$ requirements in ovarian development are well documented and appear broadly conserved among vertebrates (Fletcher \& Fletcher 1980, Versieck \& Cornelis 1989, Thompson et al. 2002). $Z_{\mathrm{B}}$ was depleted in the mature IS females from October onwards, coincidental with the early stages of oocyte production and likely caused by 
upregulation of vitellogenin, a Zn-binding protein that transports $\mathrm{Zn}$ to the ovaries (Fletcher \& Fletcher 1980). This study represents the first time Se concentrations have been measured in fish blood plasma and the first time seasonal trends in Se have been examined in any fish biofluid. $\mathrm{Se}_{\mathrm{B}}$ behaved in a similar manner to $\mathrm{Cu}_{\mathrm{B}}$, suggesting that it is primarily protein bound in the blood and important for ovarian development, a phenomenon that is already established in the human reproductive literature (Versieck \& Cornelis 1989, Bedwal \& Bahuguna 1994).

In summary, sex, maturity and reproductive condition are clearly important, influencing the transport, demand and flux of trace and minor elements in blood plasma and, consequently, their concentrations and availability for uptake into other tissues. Separating their influences from other intrinsic (e.g. growth) and extrinsic (e.g. temperature, salinity) factors could prove critical for the accurate interpretation of tissue element chemistry.

\section{Environmental effects}

For applications using otolith elemental concentrations as environmental proxies or geographic markers, the relationship between otolith composition and ambient physicochemical conditions must be well understood. Given that marine fish continually drink seawater to maintain ionic homeostasis, it is likely that the majority of hard metal ions are sourced from the surrounding seawater (e.g. Walther \& Thorrold 2006). It is often assumed that ion uptake is proportional to ambient concentrations, but here, plasma and seawater elemental concentrations were poorly correlated, and plasma microchemistry appeared to be driven primarily by physiological processes. These data emphasize the importance of the signalto-noise ratio in the application of otolith microchemistry. This is particularly important for fully marine species, which experience relatively minor environmental variations compared with their freshwater and diadromous counterparts (reviewed in Walther \& Limburg 2012). Here, for the majority of elements, variations in ambient concentrations were probably too small to produce measureable changes in the blood, with conservative and quasi-conservative $\mathrm{El} / \mathrm{Ca}$ ratios effectively constant throughout (Fig. 2). Yet experimental conditions varied according to coastal precipitation cycles, equating to salinity and temperature variations of approximately 3 and $10^{\circ} \mathrm{C}$, respectively, which would represent relatively large variations in an open-ocean setting. Laboratory ex- periments tend to manipulate ambient concentrations to ranges far greater than those experienced by marine species, essentially mimicking gradients that may be experienced during diadromous migrations (e.g. Miller 2009, Hicks et al. 2010). Here, both $\mathrm{Li}_{B}$ and $\mathrm{Mg}_{\mathrm{B}}$ values were positively related to salinity and/or temperature, although $\mathrm{Li}_{\mathrm{B}}$ was explained by a significant interaction being unrelated (or even negatively related) to temperature at low salinities. While our $\mathrm{Ba}_{\mathrm{B}}$ measurements (Sturrock et al. 2013) and model fits (Table 3 ) were relatively poor, we observed a significant interaction between $\mathrm{Ba} / \mathrm{Ca}_{\mathrm{W}}$ values and temperature, where at low temperatures there was no relationship but at higher temperatures there was a positive relationship between $\mathrm{Ba} / \mathrm{Ca}_{\mathrm{W}}$ and $\mathrm{Ba}_{\mathrm{B}}$ values. Increasing numbers of studies are reporting interactions between otolith $\mathrm{Ba} / \mathrm{Ca}$ ratios, temperature and salinity (e.g. Elsdon \& Gillanders 2002, de Vries et al. 2005, Miller 2011), adding further complexity to environmental reconstructions. Variations in $\mathrm{Mg}_{\mathrm{B}}$ values were best explained by salinity; however, the elevated $\mathrm{Mg}_{\mathrm{B}}$ and protein concentrations during summer months and the requirement of $\mathrm{Mg}^{2+}$ in almost every major metabolic pathway (Kaim \& Schwederski 1994) may also indicate higher uptake rates with increased metabolic activity. However, of all the elements examined, $\mathrm{Li}_{\mathrm{B}}$ $\mathrm{Mg}_{\mathrm{B}}$ and $\mathrm{Ba}_{\mathrm{B}}$ appeared to exhibit the least biological fractionation and, thus, the greatest potential sensitivity to environmental fluctuations.

Despite clear physiological influences on the softer elements, the strongest pairwise correlations between plasma and water elemental concentrations were for $\mathrm{Zn}$ and $\mathrm{Se}$, and for $\mathrm{Cu}$ in the (mostly immature) EC females. These correlations were largely driven by their common decreases during the winter spawning period (Fig. 4i,j,k). While utilisation of these elements in oocyte development almost certainly explains the more extreme response of the mature IS females, the trend was also exhibited by the males and immature EC females, implying additional common factors such as ambient concentration or temperature. The decrease in $\mathrm{Zn}_{\mathrm{B}}$ and $\mathrm{Cu}_{\mathrm{B}}$ values more closely coincided with cooling water temperatures, and a positive temperature effect was included in both models; however, the mechanism remains unresolved. While the elemental composition of the diet was not formally quantified, bulk concentrations of the soft elements were typically orders of magnitude higher than in seawater (M. J. Cooper unpubl.). Thus, seasonal shifts in feeding activity may have contributed to the observed trends in plasma concentrations. Without quantifying the elemental composi- 
tion of digested and excreted tissues, it would be impossible to fully partition dietary vs. waterborne sources. However, the fact that blood plasma concentrations of the soft elements did not fully covary suggests that the observed differences between the sexes were not simply an artefact of sex-specific feeding behaviours. Experimental work has suggested that diet contributes the majority of tissue Mn, $\mathrm{Cu}$ and $\mathrm{Zn}$ (Pentreath 1973, 1976) and otolith Zn (Ranaldi \& Gagnon 2008). Several field studies have failed to find a relationship between otolith and water Zn concentrations (Thorrold et al. 1997, Hanson \& Zdanowicz 1999, Warner et al. 2005), while the high $D_{Z n(B / W)}$ value further suggests a non-aqueous source of $\mathrm{Zn}$. As such, we postulate that the common decrease in $\mathrm{Zn}_{\mathrm{B}}$ during winter resulted from reduced feeding activity, although the earlier and more acute trend in the mature females almost certainly reflected active removal for vitellogenesis (Fletcher \& Fletcher 1978). Unlike $\mathrm{Zn}$, both experimental and field studies have reported positive relationships between ambient and otolith Se concentrations (Limburg et al. 2010, Lochet et al. 2010), and the patterns in $\mathrm{Se}_{\mathrm{B}}$ observed here, while inferring additive effects of ontogeny, support these findings. Correlations between seawater and otolith $\mathrm{Cu}$ concentrations have been observed in juvenile fish in the laboratory (Milton \& Chenery 2001) but not in the field (Hanson \& Zdanowicz 1999). Here, positive relationships between $\mathrm{Cu}_{\mathrm{W}}$ and $\mathrm{Cu}_{\mathrm{B}}$ values were only observed in the immature EC females, implying that reproductive effects dominate tissue concentrations of $\mathrm{Cu}$ following sexual maturity. Validation work including both mature and immature subject animals will be critical to understanding the underlying processes.

Studies using otolith microchemistry to infer geographic distributions of fish often do so without prior validation and assume a level of environmental sensitivity (and variability) that may be grossly overestimated. For studies examining stock structure or group contributions during mixing events, it is not as critical to understand the underlying mechanisms, so long as all potential groups have been representatively sampled and exhibit unique and reproducible chemical 'fingerprints' (Campana 2005, Elsdon et al. 2008). However, to reconstruct lifetime movements from otolith chemical profiles, several assumptions need to be met, including the assumption that otolith chemistry changes predictably with environmental parameters and that ontogenetic effects on otolith chemistry are known (Elsdon et al. 2008). If unaccounted for, physiologically driven changes in blood and otolith chemistry and sex- and stage-specific differ- ences in elemental processing mechanisms could undermine both assumptions. Populations exhibiting skewed or variable sex ratios or sex-related dispersal patterns (e.g. Consuegra \& García de Leániz 2007) could be vulnerable to mismanagement if their spatial dynamics are interpreted using physiologically sensitive markers. Ontogenetic effects on otolith Sr incorporation have been observed in several species (De Pontual et al. 2003, Brown \& Severin 2009, Walther et al. 2010), but limited data are available for other elements. In our eagerness to use otoliths as the 'black box recorders' they are so often compared to, there is a danger for elemental data to be misinterpreted, which could seriously impact management decisions and progress within the field. While meeting the full suite of assumptions required for determining lifetime movements and life history patterns is beyond the scope of most studies (Elsdon et al. 2008), it is critical that validation studies continue and sampling efforts control for sex and age wherever possible.

Acknowledgements. This research was funded by a Fisheries Society of the British Isles PhD studentship to A.M.S. and Defra contract M1102 MEMFISH (macroecology of marine finfish in UK waters). We are grateful to the many CEFAS staff who aided in sample collection and animal husbandry, particularly C. Stewart, S. Hetherington, M. Eade, M. Smith, A. Pliru, J. Pettigrew, L. Privitera and S. Milligan. Constructive comments were provided by R. Johnson (University of California, Santa Cruz) and 3 anonymous reviewers. We appreciate the statistical support provided by $\mathrm{R}$. Inger (University of Exeter), P. Challenor (University of Southampton) and M. Buoro (University of California, Berkeley) and the advice and shared datasets provided by J. Kennedy (Møreforsking Marin).

\section{LITERATURE CITED}

Abramoff MD, Magelhaes PJ, Ram SJ (2004) Image processing with ImageJ. Biophotonics Int 11:36-42

Andreasen P (1985) Free and total calcium concentrations in the blood of rainbow trout, Salmo gairdneri, during 'stress' conditions. J Exp Biol 118:111-120

> Bath GE, Thorrold SR, Jones CM, Campana SE, Mclaren JW, Lam JWH (2000) Strontium and barium uptake in aragonitic otoliths of marine fish. Geochim Cosmochim Acta 64:1705-1714

> Bedwal RS, Bahuguna A (1994) Zinc, copper and selenium in reproduction. Cell Mol Life Sci 50:626-640

Ben-Tzvi O, Abelson A, Gaines SD, Sheehy MS, Paradis GL, Kiflawi M (2007) The inclusion of sub-detection limit LAICPMS data, in the analysis of otolith microchemistry, by use of a palindrome sequence analysis (PaSA). Limnol Oceanogr Methods 5:97-105

> Bourne PK (1986) Changes in haematological parameters associated with capture and captivity of the marine teleost, Pleuronectes platessa L. Comp Biochem Physiol A 85:435-443

Bromley PJ (2000) Growth, sexual maturation and spawning 
in central North Sea plaice (Pleuronectes platessa L.), and the generation of maturity ogives from commercial catch data. J Sea Res 44:27-43

Brown RJ, Severin KP (2009) Otolith chemistry analyses indicate that water $\mathrm{Sr}: \mathrm{Ca}$ is the primary factor influencing otolith $\mathrm{Sr}: \mathrm{Ca}$ for freshwater and diadromous fish but not for marine fish. Can J Fish Aquat Sci 66:1790-1808

Campana SE (1999) Chemistry and composition of fish otoliths: pathways, mechanisms and applications. Mar Ecol Prog Ser 188:263-297

Campana SE (2005) Otolith elemental composition as a natural marker of fish stocks. In: Cadrin SX, Friedland KD, Waldman JR (eds) Stock identification methods: applications in fishery science. Elsevier, Burlington, MA, p 227-245

> Clarke LM, Thorrold SR, Conover DO (2011) Population differences in otolith chemistry have a genetic basis in Menidia menidia. Can J Fish Aquat Sci 68:105-114

Cleveland WS, Grosse E, Shyu WM (1992) Local regression models. In: Chambers JM, Hastie TJ (eds) Statistical models in S. Chapman \& Hall, New York, p 309-376

Cobb JLS, Fox NC, Santer RM (1973) A specific ringer solution for the plaice (Pleuronectes platessa L.). J Fish Biol 5: 587-591

> Consuegra S, García de Leániz C (2007) Fluctuating sex ratios, but no sex-biased dispersal, in a promiscuous fish. Evol Ecol 21:229-245

Crawley MJ (2007) The R book. John Wiley \& Sons, Chichester

$>$ Dawson AS, Grimm AS (1980) Quantitative seasonal changes in the protein, lipid and energy content of the carcass, ovaries and liver of adult female plaice, Pleuronectes platessa L. J Fish Biol 16:493-504

> De Pontual H, Lagardère F, Amara R, Bohn M, Ogor A (2003) Influence of ontogenetic and environmental changes in the otolith microchemistry of juvenile sole (Solea solea). J Sea Res 50:199-211

de Vries MC, Gillanders BM, Elsdon TS (2005) Facilitation of barium uptake into fish otoliths: influence of strontium concentration and salinity. Geochim Cosmochim Acta 69: 4061-4072

Elsdon TS, Gillanders BM (2002) Interactive effects of temperature and salinity on otolith chemistry: challenges for determining environmental histories of fish. Can J Fish Aquat Sci 59:1796-1808

Elsdon TS, Wells BKC, Gillanders SE, Jones BM and others (2008) Otolith chemistry to describe movements and lifehistory parameters of fishes: hypotheses, assumptions, limitations, and inferences. Oceanogr Mar Biol Annu Rev 46:297-330

Evans DH (1993) The physiology of fishes. CRC Press, Boca Raton, FL

Fletcher PE, Fletcher GL (1978) The binding of zinc to the plasma of winter flounder (Pseudopleuronectes americanus): affinity and specificity. Can J Zool 56:114-120

Fletcher PE, Fletcher GL (1980) Zinc- and copper-binding proteins in the plasma of winter flounder (Pseudopleuronectes americanus). Can J Zool 58:609-613

Folmar LC, Moody T, Bonomelli S, Gibson J (1992) Annual cycle of blood chemistry parameters in striped mullet (Mugil cephalus L.) and pinfish (Lagodon rhomboides L.) from the Gulf of Mexico. J Fish Biol 41:999-1011

Fonds M, Cronie R, Vethaak AD, Van Der Puyl P (1992) Metabolism, food consumption and growth of plaice (Pleuronectes platessa) and flounder (Platichthys flesus) in relation to fish size and temperature. Neth J Sea Res 29:127-143
Hanson PJ, Zdanowicz VS (1999) Elemental composition of otoliths from Atlantic croaker along an estuarine pollution gradient. J Fish Biol 54:656-668

Harding D, Nichols JH, Tungate DS (1978) The spawning of the plaice (Pleuronectes platessa L.) in the southern North Sea and English Channel. Rapp P-V Reùn Cons Int Explor Mer 172:102-113

Hicks AS, Closs GP, Swearer SE (2010) Otolith microchemistry of two amphidromous galaxiids across an experimental salinity gradient: a multi-element approach for tracking diadromous migrations. J Exp Mar Biol Ecol 394:86-97

- Hille S (1982) A literature review of the blood chemistry of rainbow trout, Salmo gairdneri Rich. J Fish Biol 20: 535-569

> Hoarau G, Piquet AMT, Van Der Veer HW, Rijnsdorp AD, Stam WT, Olsen JL (2004) Population structure of plaice (Pleuronectes platessa L.) in northern Europe: a comparison of resolving power between microsatellites and mitochondrial DNA data. J Sea Res 51:183-190

- Horwood JW, Walker MG, Witthames P (1989) The effect of feeding levels on the fecundity of plaice (Pleuronectes platessa). J Mar Biol Assoc UK 69:81-92

> Hunter E, Metcalfe JD, Arnold GP, Reynolds JD (2004) Impacts of migratory behaviour on population structure in North Sea plaice. J Anim Ecol 73:377-385

- Hurlbert SH (1984) Pseudoreplication and the design of ecological field experiments. Ecol Monogr 54:187-211

> Kacem A, Gustafsson S, Meunier FJ (2000) Demineralization of the vertebral skeleton in Atlantic salmon Salmo salar L. during spawning migration. Comp Biochem Physiol A 125:479-484

Kaim W, Schwederski B (1994) Bioinorganic chemistry: inorganic elements in the chemistry of life. John Wiley \& Sons, Chichester

Kalish JM (1989) Otolith microchemistry: validation of the effects of physiology, age and environment on otolith composition. J Exp Mar Biol Ecol 132:151-178

Kalish JM (1991) Determinants of otolith chemistry: seasonal variation in the composition of blood plasma, endolymph and otoliths of bearded rock cod Pseudophysis barbatus. Mar Ecol Prog Ser 74:137-159

Kennedy J, Witthames PR, Nash RDM, Fox CJ (2008) Is fecundity in plaice (Pleuronectes platessa L.) downregulated in response to reduced food intake during autumn? J Fish Biol 72:78-92

Kremling K (1999) Determination of trace metals. In: Grasshoff K, Kremling K, Ehrhardt M (eds) Methods of seawater analysis. Wiley-VCH, Weinheim, p 253-364

> Limburg KE, Lochet A, Driscoll D, Dale DS, Huang R (2010) Selenium detected in fish otoliths: a novel tracer for a polluted lake? Environ Biol Fishes 89:433-440

Lochet A, Limburg KE, Rudstam L, Montesdeoca M (2010) Selenium incorporation in fish otoliths: effects of selenium and mercury from the water. Can J Fish Aquat Sci 67:1388-1397

Macdonald JI, Crook DA (2010) Variability in Sr:Ca and Ba: $\mathrm{Ca}$ ratios in water and fish otoliths across an estuarine salinity gradient. Mar Ecol Prog Ser 413:147-161

Maddock DM, Burton MPM (1998) Gross and histological observations of ovarian development and related condition changes in American plaice. J Fish Biol 53:928-944

Martin GB, Thorrold SR, Jones CM (2004) Temperature and salinity effects on strontium incorporation in otoliths of larval spot (Leiostomus xanthurus). Can J Fish Aquat Sci 61:34-42

> Martinez CBR, Nagae NY, Zaia CTBV, Zaia DM (2004) 
Acute morphological and physiological effects of lead in the neotropical fish Prochilodus lineatus. Braz J Biol 64: 797-807

Melancon S, Fryer BJ, Markham JL (2009) Chemical analysis of endolymph and the growing otolith: fractionation of metals in freshwater fish species. Environ Toxicol Chem 28:1279-1287

Miller JA (2009) The effects of temperature and water concentration on the otolith incorporation of barium and manganese in black rockfish Sebastes melanops. J Fish Biol 75:39-60

Miller JA (2011) Effects of water temperature and barium concentration on otolith composition along a salinity gradient: implications for migratory reconstructions. J Exp Mar Biol Ecol 405:42-52

> Milton DA, Chenery SR (2001) Sources and uptake of trace metals in otoliths of juvenile barramundi (Lates calcarifer). J Exp Mar Biol Ecol 264:47-65

Mugiya Y (1966) Calcification in fish and shellfish. Seasonal change in calcium and magnesium concentration of the otolith fluid in some fish with special reference to the zone formation of their otolith. Bull Jpn Soc Sci Fish 32: 549-557

> Nagelkerke NJD (1991) A note on a general definition of the coefficient of determination. Biometrika 78:691-692

Payan P, Borelli G, Priouzeau F, De Pontual H, Bœuf G, Mayer-Gostan N (2002) Otolith growth in trout Oncorhynchus mykiss: supply of $\mathrm{Ca}^{2+}$ and $\mathrm{Sr}^{2+}$ to the saccular endolymph. J Exp Biol 205:2687-2695

> Payan P, De Pontual H, Edeyer A, Borelli G, Bœuf G, MayerGostan N (2004a) Effects of stress on plasma homeostasis, endolymph chemistry, and check formation during otolith growth in rainbow trout (Oncorhynchus mykiss). Can J Fish Aquat Sci 61:1247-1255

Payan P, De Pontual H, Bœuf G, Mayer-Gostan N (2004b) Endolymph chemistry and otolith growth in fish. C R Palevol 3:535-547

Pentreath RJ (1973) The accumulation and retention of ${ }^{65} \mathrm{Zn}$ and ${ }^{54} \mathrm{Mn}$ by the plaice, Pleuronectes platessa L. J Exp Mar Biol Ecol 12:1-18

> Pentreath RJ (1976) Some further studies on the accumulation and retention of ${ }^{65} \mathrm{Zn}$ and ${ }^{54} \mathrm{Mn}$ by the plaice, Pleuronectes platessa L. J Exp Mar Biol Ecol 21:179-189

Ranaldi MM, Gagnon MM (2008) Zinc incorporation in the otoliths of juvenile pink snapper (Pagrus auratus Forster): the influence of dietary versus waterborne sources. J Exp Mar Biol Ecol 360:56-62

Rijnsdorp AD (1989) Maturation of male and female North Sea plaice (Pleuronectes platessa L.). J Cons 46:35-51

Rijnsdorp AD (1990) The mechanism of energy allocation over reproduction and somatic growth in female North Sea plaice, Pleuronectes platessa L. Neth J Sea Res 25: 279-290

Sadovy Y, Severin KP (1994) Elemental patterns in red hind (Epinephelus guttatus) otoliths from Bermuda and Puerto Rico reflect growth rate, not temperature. Can J Fish Aquat Sci 51:133-141

Scott P, Witthames PR, Turner RJ, Canario AVM (1998) Plasma concentrations of ovarian steroids in relation to oocyte final maturation and ovulation in female plaice sampled at sea. J Fish Biol 52:128-145

Shearer KD (1984) Changes in elemental composition of hatchery-reared rainbow trout, Salmo gairdneri, associated with growth and reproduction. Can J Fish Aquat Sci 41:1592-1600

Steele JH, Thorpe SA, Turekian KK (eds) (2009) Marine chemistry and geochemistry: a derivative of the encyclopedia of ocean sciences. Academic Press, Burlington, MA

Sturrock AM (2012) Environmental and physiological influences on otolith chemistry in a marine fish. PhD dissertation, University of Southampton

> Sturrock AM, Trueman CN, Darnaude AM, Hunter E (2012) Can otolith elemental chemistry retrospectively track migrations in fully marine fishes? J Fish Biol 81:766-795

Sturrock AM, Hunter E, Milton JA, Trueman CN (2013) Analysis methods and reference concentrations of 12 minor and trace elements in fish blood plasma. J Trace Elem Med Biol 27:273-285

Thompson ED, Mayer GD, Walsh PJ, Hogstrand C (2002) Sexual maturation and reproductive zinc physiology in the female squirrelfish. J Exp Biol 205:3367-3376

Thorrold SR, Jones CM, Campana SE (1997) Response of otolith microchemistry to environmental variations experienced by larval and juvenile Atlantic croaker (Micropogonias undulatus). Limnol Oceanogr 42:102-111

Tohse H, Mugiya Y (2001) Effects of enzyme and anion transport inhibitors on in vitro incorporation of inorganic carbon and calcium into endolymph and otoliths in salmon Oncorhynchus masou. Comp Biochem Physiol A 128:177-184

Underwood EJ (1977) Trace elements in human and animal nutrition, 4th edn. Academic Press, New York

Urist MR, Schjeide AO (1961) The partition of calcium and protein in the blood of oviparous vertebrates during estrus. J Gen Physiol 44:743-756

> Valtonen T, Laitinen M (1988) Acid stress in respect to calcium and magnesium concentrations in the plasma of perch during maturation and spawning. Environ Biol Fishes 22:147-154

Versieck J, Cornelis R (1989) Trace elements in human plasma or serum. CRC Press, Boca Raton, FL

Walther BD, Limburg KE (2012) The use of otolith chemistry to characterize diadromous migrations. J Fish Biol 81: 796-825

- Walther BD, Thorrold SR (2006) Water, not food, contributes the majority of strontium and barium deposited in the otoliths of a marine fish. Mar Ecol Prog Ser 311: 125-130

Walther BD, Kingsford MJ, O'Callaghan MD, McCulloch MD (2010) Interactive effects of ontogeny, food ration and temperature on elemental incorporation in otoliths of a coral reef fish. Environ Biol Fishes 89:441-451

Waring CP, Stagg RM, Poxton MG (1992) The effects of handling on flounder (Platichthys flesus L.) and Atlantic salmon (Salmo salar L.). J Fish Biol 41:131-144

Waring CP, Stagg RM, Poxton MG (1996) Physiological responses to handling in the turbot. J Fish Biol 48:161-173

Warner R, Swearer S, Caselle J, Sheehy M, Paradis G (2005) Natal trace-elemental signatures in the otoliths of an open-coast fish. Limnol Oceanogr 50:1529-1542

> Watts PC, Nash RDM, Kemp SJ (2004) Genetic structure of juvenile plaice Pleuronectes platessa on nursery grounds within the Irish Sea. J Sea Res 51:191-197

Williams DR (1971) The metals of life. Van Nostrand Reinhold, London

- Woodhead PMJ (1968) Seasonal changes in the calcium content of the blood of arctic cod. J Mar Biol Assoc UK 48: 81-91

Zuur AF, Ieno EN, Walker NJ, Saveliev AA, Smith GM (2009) Mixed effects models and extensions in ecology with R. Springer, New York

Submitted: September 12, 2013; Accepted: December 13, 2013 Proofs received from author(s): March 7, 2014 